\title{
A modeling assessment of the interplay between aeolian iron fluxes and iron-binding ligands in controlling carbon dioxide fluctuations during Antarctic warm events
}

\author{
Payal Parekh, ${ }^{1}$ Fortunat Joos, ${ }^{1,2}$ and Simon A. Müller ${ }^{1,3}$ \\ Received 8 August 2007; revised 4 June 2008; accepted 1 July 2008; published 4 October 2008.
}

[1] We add a prognostic biogeochemical model to the Bern3D ocean circulation model to test the impact of increased aeolian iron fluxes in various regions of the ocean on long time scales. Atmospheric $\mathrm{CO}_{2}$ is most sensitive when modern dust flux is increased 100-fold in the Southern Ocean for 1000 years, resulting in a reduction of 10 ppmv. Seeding the Indian Ocean and South Pacific results in increased export production and $\mathrm{CO}_{2}$ drawdown in the Southern Ocean due to interbasinal transport of iron. The non-sea-salt calcium record from Dome C, Antarctica, is used to scale aeolian iron deposition in the Southern Ocean in transient simulations over four Antarctic warm events of the last glacial period. Our results suggest changes in dust flux to the Southern Ocean played a limited role in modulating $\mathrm{CO}_{2}$ variations. The impact of iron fluxes on $\mathrm{CO}_{2}$ is dependent on parameter values chosen for the iron-binding ligand.

Citation: Parekh, P., F. Joos, and S. A. Müller (2008), A modeling assessment of the interplay between aeolian iron fluxes and iron-binding ligands in controlling carbon dioxide fluctuations during Antarctic warm events, Paleoceanography, 23, PA4202, doi:10.1029/2007PA001531.

\section{Sensitivity of Atmospheric $\mathrm{CO}_{2}$ to Aeolian Dust Flux}

[2] Martin [1990] suggested that an increase in dust flux and supply of iron could have fertilized the ocean and increased the efficiency of the soft-tissue biological pump, thereby decreasing atmospheric carbon dioxide $\left(\mathrm{CO}_{2}\right)$. This is consistent with evidence of an increase in the aeolian source of dust during glacial periods [Petit et al., 1999; Röthlisberger et al., 2004]. In situ iron fertilization studies have been carried out in oceanic regions with low $\mathrm{Fe}$ concentrations, high surface concentrations of macronutrients and low chlorophyll (referred to as HNLC regions) [Martin et al., 1994; Coale et al., 1996, 2004; Boyd et al., 2000; Tsuda et al., 2003; Boyd et al., 2004]. These experiments have clearly demonstrated a response in primary production to the addition of iron. Early studies were not able to conclusively indicate any associated increase in export of carbon [Charette and Buesseler, 2000]. More recently, there is evidence of increased export production as a response to iron fertilization in the Southern Ocean [Buesseler et al., 2004] and in the Gulf of Alaska [Boyd et al., 2004].

[3] Coupled biogeochemical and circulation models have been used to assess the sensitivity of marine productivity

\footnotetext{
${ }^{1}$ Climate and Environmental Physics, Physics Institute, University of Bern, Bern, Switzerland.

${ }^{2}$ Also at Oeschger Centre for Climate Change Research, University of Bern, Bern, Switzerland.

${ }^{3}$ Now at Department of Earth and Environmental Sciences, Open University, Milton Keynes, UK.

Copyright 2008 by the American Geophysical Union. 0883-8305/08/2007PA001531\$12.00
}

and atmospheric $\mathrm{CO}_{2}$ to increased aeolian iron flux. Earlier models, which lacked an iron cycle, suggest that iron fertilization could reduce atmospheric $\mathrm{CO}_{2}$ between 34 ppmv and 59 ppmv assuming no anthropogenic emissions [Joos et al., 1991; Peng and Broecker, 1991; Kurz and Maier-Reimer, 1993]. The inclusion of "business as usual" anthropogenic $\mathrm{CO}_{2}$ emissions results in a drawdown of $\mathrm{CO}_{2}$ ranging between 50 and 107 ppmv [Joos et al., 1991; Sarmiento and Orr, 1991; Kurz and Maier-Reimer, 1993]. Since these models did not include an iron cycle, they assumed that iron additions would completely deplete phosphate in surface waters of HNLC regions. Limitation by light or silicate may also prevent the complete drawdown of surface phosphate. Furthermore, ambient ligand concentration and strength (quantified by the conditional stability constant) affect the ability of added iron to remain soluble in ocean waters, which may not allow for the complete removal of iron limitation. Particle scavenging would also result in a loss of added iron. Thus these should be considered as upper bound estimates of changes in atmospheric $\mathrm{CO}_{2}$ due to the addition of iron.

[4] Three-dimensional ocean circulation models that include a prognostic description of the iron cycle predict much smaller changes to atmospheric $\mathrm{CO}_{2}$ due to global increases in dust flux [Dutkiewicz et al., 2005; Parekh et al., 2006a], Last Glacial Maximum (LGM) dust fluxes [Archer and Johnson, 2000; Archer et al., 2000; Bopp et al., 2003; Parekh et al., 2006b] and potential future increases in dust flux under modern fossil fuel emissions [Aumont and Bopp, 2006]. For example, Aumont and Bopp [2006] calculate an increase in primary production and export production of $9.7 \mathrm{Gt} \mathrm{C} \mathrm{a}^{-1}$ and $1.8 \mathrm{Gt} \mathrm{C} \mathrm{a}^{-1}$, respectively, and a $\mathrm{CO}_{2}$ drawdown of $33 \mathrm{ppmv}$ when mixed layer iron concentrations are set to $2 \mathrm{nM}$ over the whole ocean for 100 years under modern 

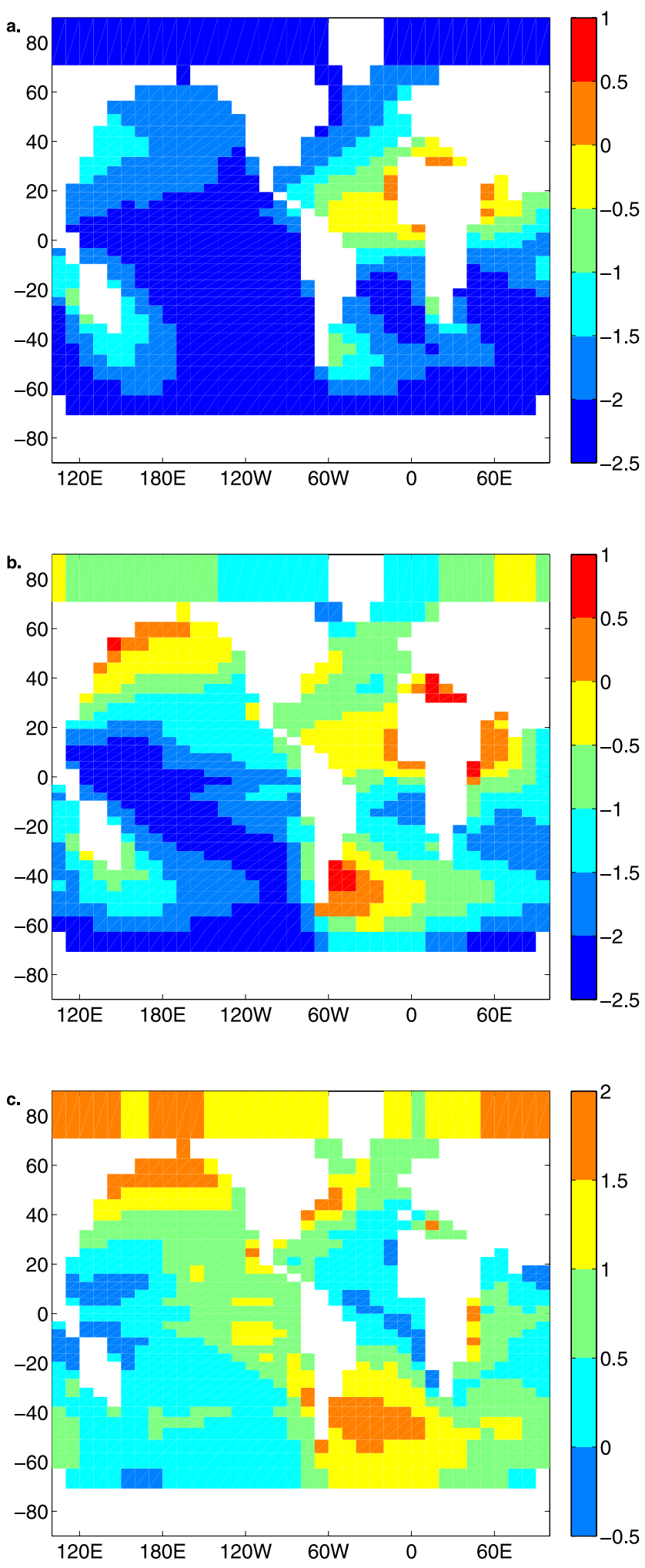

Figure 1. A comparison between (a) modern dust forcing [Luo et al., 2003], (b) LGM dust forcing [Mahowald et al., 2006], and (c) the difference between the two (LGMModern). All fields represent a yearly average $\left(\log _{10}\left(\frac{F_{F e}}{F_{\text {ref }}}\right)\right.$, where $\mathrm{F}_{r e f}=1 \mathrm{~g} \mathrm{~m}^{-2} \mathrm{a}^{-1}$ ). In the case of the difference plot, $\mathrm{F}_{F e}=\mathrm{Fe}_{L G M}-\mathrm{Fe}_{\text {modern }}$. fossil fuel emissions. In contrast, Dutkiewicz et al. [2005] find that a ten fold increase in iron flux for preindustrial conditions results in an increase in primary production and export production of $1.9 \mathrm{Gt} \mathrm{C} \mathrm{a}^{-1}$ and $0.65 \mathrm{Gt} \mathrm{C} \mathrm{a}^{-1}$, respectively.

[5] These studies focused on the effect of increased dust flux in the Southern Ocean or globally. We extend these studies to include the impact of increased dust fluxes in various regions of the ocean (other HNLC, as well nonHNLC regions). Our study is motivated by the difference in dust flux patterns for the LGM [Mahowald et al., 2006] to today [Luo et al., 2003]. For example, a reconstruction of equatorial Pacific aeolian dust flux derived from marine sediments show that dust flux was approximately 2.5 times higher in this region during the LGM compared to today [Winckler et al., 2008], while dust measured in the Dome C ice core indicates that dust flux was 25 fold higher in Antarctica during the LGM [Lambert et al., 2008]. Such a variance in dust patterns between the LGM and preindustrial fluxes (Figure 1) suggest that dust input into regions such as the Southern Ocean or the North Pacific may be responsible for a bulk of the $\mathrm{CO}_{2}$ drawdown caused by iron. In the first part of our study, we use the Bern3D model, an ocean circulation model with a biogeochemical component that includes a fully prognostic representation of the oceanic iron and phosphorus cycles, to test the sensitivity of atmospheric $\mathrm{CO}_{2}$ to aeolian iron flux increases in various regions of the ocean.

[6] Ice core records from Antarctica show millennialscale variability in methane and carbon dioxide over the last 800,000 years [Loulergue et al., 2008; Lüthi et al., 2008]. For example, during A1 to A4, the last four warm events of the last glacial period, $\mathrm{CO}_{2}$ varied between 196 and 220 ppmv [Indermühle et al., 2000; Ahn and Brook, 2007]. Changes in circulation strength, causing a release of carbon from the ocean [Marchal et al., 1999] and land [Köhler et al., 2005; Scholze et al., 2003], have been suggested as possible triggers that may explain the changes in atmospheric $\mathrm{CO}_{2}$. Comparing the non-sea-salt calcium (nss- $\mathrm{Ca}^{2+}$ ) record, a proxy for dust flux, at Dome C, Antarctica with the Taylor Dome, Antarctica $\mathrm{CO}_{2}$ record, Röthlisberger et al. [2004] found an inverse relationship between dust flux and $\mathrm{CO}_{2}$ concentrations during $\mathrm{A} 1$ to $\mathrm{A} 4$ (Figure 2). The synchronicity or lead/lag between the two records cannot be firmly established because of uncertainties in the dating of the cores and the $\Delta$ age model; the uncertainty is estimated to be between 900 and 1500 years [Loulergue et al., 2007, J. Schwander, personal communication, 2008]. Nevertheless, a possible explanation for these relatively small fluctuations in atmospheric $\mathrm{CO}_{2}$ could be due to variations in aeolian supply of Fe. In the second part of our study we perform a transient run, forcing the Bern3D model with the dust deposition record from Dome $\mathrm{C}$ during Antarctic warm events A1 to A4.

[7] The purpose of this study is (1) to investigate the link between aeolian iron input, export production and atmospheric $\mathrm{CO}_{2} ;$ (2) to explore how reconstructed changes in Southern Ocean dust deposition could have contributed to $\mathrm{CO}_{2}$ variations during the last glacial period 60 to 30 thousand years before present; (3) to address the 


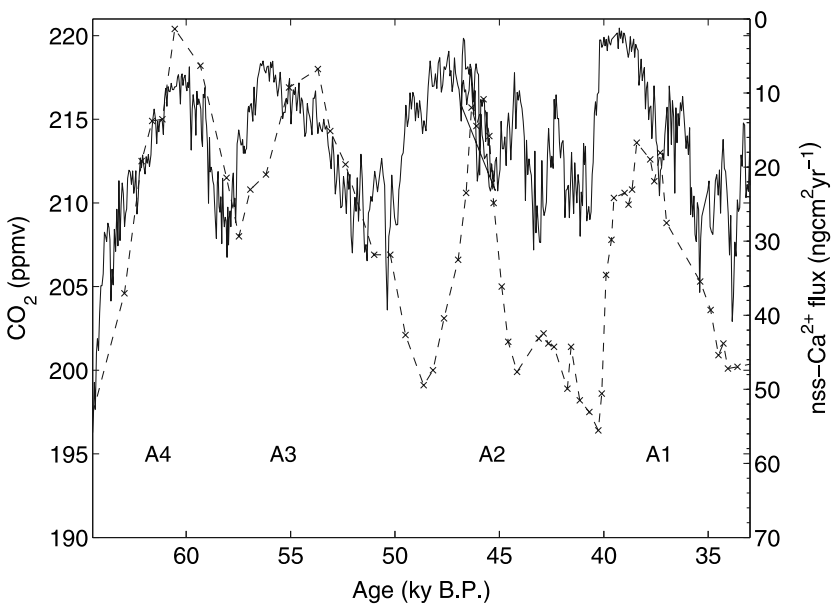

Figure 2. $\mathrm{CO}_{2}$ (ppmv, dashed curve) record from Taylor Dome, Antarctica [Indermühle et al., 2000], and the nss$\mathrm{Ca}^{2+}$ flux (ng $\mathrm{cm}^{-2} \mathrm{a}^{-1}$, solid curve) from Dome $\mathrm{C}$ [Röthlisberger et al., 2004], a proxy for dust flux, plotted against time. The SS09sea time scale is applied. The crosses represent the actual data points. Error in $\mathrm{CO}_{2}$ measurements ranges between 0.2 and $1.1 \mathrm{ppmv}$. Note that the $y$ axis of the nss- $\mathrm{Ca}^{2+}$ flux is reversed. A1 to A4 are the last four warm events of the last glacial period in Antarctica.

role of iron transport between different ocean basins; and (4) to consider the sensitivity of $\mathrm{CO}_{2}$ to iron-binding ligand strength and concentration. We apply the Bern3D ocean-biogeochemical model to a range of equilibrium and transient simulations.

\section{Iron and Primary Productivity}

[8] Iron is an essential micronutrient for marine phytoplankton, involved in key metabolic processes such as photosynthetic and respiratory electron transport, nitrate and nitrite reduction, $\mathrm{N}_{2}$ fixation and sulfate reduction [Sunda, 2001; Barbeau, 2006]. Although iron is the fourth most abundant element in the Earth's crust, it has been present in seawater in extremely low concentrations since at least the Proterozoic because of the hydrolysis of thermodynamically stable Fe(III), forming insoluble hydroxides and oxides (i.e., inorganic precipitation).

[9] The primary sources of iron to the open ocean are aeolian dust [Duce and Tindale, 1991] and continental margin sediments [Johnson et al., 1999]. Both sources can vary over time because of changes in vegetation cover and winds [Mahowald et al., 1999] or because of changes in sediment dissolution. In regions of the ocean that are far from these continental sources of iron, primary productivity is limited by the lack of iron. These areas are found in the equatorial Pacific, North Pacific and the Southern Ocean. They are known as high-nitrate, low-chlorophyll (HNLC) regions and are characterized by high surface concentrations of macronutrients (nitrate, phosphate and silicate), but relatively low algal biomass.

[10] Recent evidence suggests that only a minor fraction of "dissolved" iron (i.e., size fraction $<0.4 \mu \mathrm{m}$ ) is truly soluble $(<0.02 \mu \mathrm{m})$, the majority actually being colloidal
[Wu et al., 2001; Cullen et al., 2006]. Colloidal iron concentrations are highest at the surface and decrease with depth because of scavenging by sinking particles, while soluble iron has a nutrient-like profile [Wu et al., 2001; Hunter and Boyd, 2007].

[11] The bioavailability of iron is dependent on its speciation in seawater. Field studies indicate that over $99 \%$ of dissolved iron is bound to organic ligands [Gledhill and van den Berg, 1994; Rue and Bruland, 1995]. This soluble form of iron is believed to be more biologically available than refractory iron hydroxides and oxides and serves to prevent the loss of iron due to inorganic precipitation and scavenging (i.e., absorption onto particles followed by sinking). It appears that two iron-binding ligand classes exist in the open ocean, a strong ligand class $\left(\mathrm{L}_{1}\right)$ which is present only in the upper oceanic water column with a conditional stability constant with respect to $\mathrm{Fe}(\mathrm{III})$ ' on the order of $10^{13} \mathrm{M}^{-1}$ and a weaker class of ligands $\left(\mathrm{L}_{2}\right)$ found in both surface and deep waters with a conditional stability constant ranging between $10^{10}$ and $10^{13} \mathrm{M}^{-1}$ [Barbeau, 2006]. Estimates of the ligand concentration range between 0.5 and $6 \mathrm{nM}$ [Parekh et al., 2004, 2005] in the open ocean.

[12] The source(s), sink(s) and chemical characterization of these iron chelators are poorly understood. Extraction of iron-binding compounds from seawater and characterization of certain functional groups within the compound reveal that functional groups known to be present in marine and terrestrial siderophores are present in the marine environment [Macrellis et al., 2001; McCormack et al., 2003; Gledhill et al., 2004]. This suggests that the strong ligand is produced biologically by bacteria to aid in the uptake of Fe from seawater. Laboratory evidence shows that planktonic marine bacteria in culture are capable of producing siderophores in response to iron stress [Trick et al., 1983; Haygood et al., 1993]. It has been proposed that the weaker ligand $\left(\mathrm{L}_{2}\right)$ could be composed of porphyrins since the conditional stability constant of these compounds is within the range observed for $\mathrm{L}_{2}$ ligands [Rue and Bruland, 1995; Witter et al., 2000]. Alternatively, the weaker ligand could be refractory in nature, analogous to humic material, a degradation product of organic matter [Rue and Bruland, 1995, 1997]. Laboratory studies using both cultured organisms and natural assemblages suggest that prokaryotic organisms (such as cyanobacteria) can access iron bound to $L_{1}$ type ligands (i.e., siderophores), while eukaryotic organisms (such as diatoms) utilize iron bound to $L_{2}$-type ligands (porphyrins) [Hutchins et al., 1999].

[13] What controls the production of the ligand is not clear, although in situ production of $\mathrm{L}_{1}$-type ligands has been observed to increase over several days in response to iron fertilization during mesoscale iron addition experiments in the equatorial Pacific and Southern Oceans [Rue and Bruland, 1997; Croot et al., 2001; Boye et al., 2005]. This implies that during glacial times, when dust flux was elevated, ambient oceanic ligand concentrations could have also been higher than today.

[14] There is no reason to expect that the distribution of ligand strength remained constant over geological time. Analysis of complexation data from other trace metals suggests that a range of ligand strengths exists in natural 


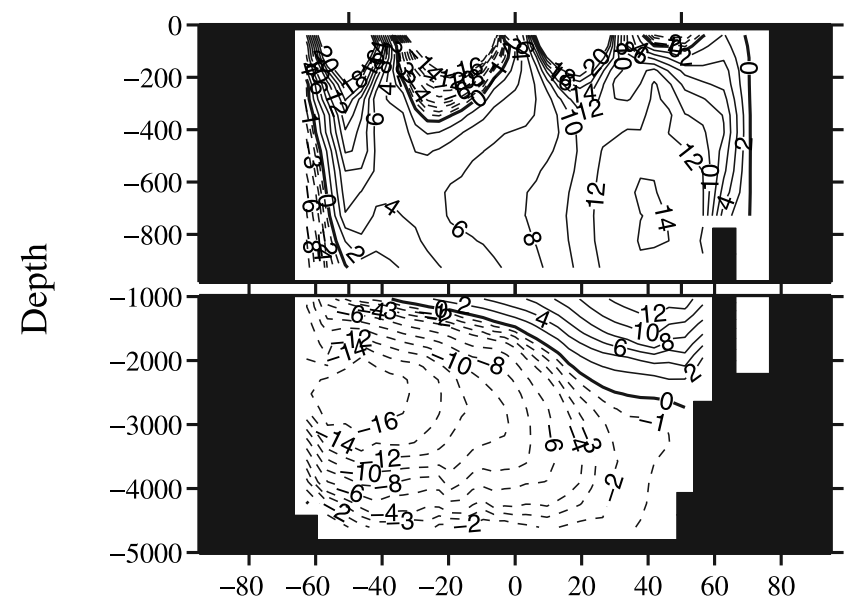

Latitude

Figure 3. The global mean overturning circulation of the model including the contribution resulting from the GentMcWilliams eddy transport parameterization. Stream function in $\mathrm{Sv}\left(10^{6} \mathrm{~m}^{3} \mathrm{~s}^{-1}\right)$.

waters rather than two size classes [Town and Filella, 2000; Voelker and Kogut, 2001]. This likely holds true for iron as well, since existing measurement methods are not capable of resolving more than one or two classes [Hunter and Boyd, 2007]. Thus, one could envision under various scenarios, in which one ligand class is more dominant than the other. For example, if the weaker ligand is actually a degradation product of organic matter [Rue and Bruland, 1995; Witter et al., 2000], during times of higher biological productivity, ligands of the weaker size class would dominate. Additionally, community structure changes that result in a lower population of bacteria would result in stronger ligands playing a less important role. Photolysis is also another process that converts siderophores into weaker ligands [Barbeau et al., 2001]. Changes in the rate of photolysis would then change the production rate of weaker ligands.

[15] Our understanding of controls on ligand strength and production are tenuous. While it is not possible to definitively state what the ligand strength and concentration were during other times in the geological past, we can speculate that if certain factors change such as aeolian iron input, rates of export production, photolysis, community structure, scavenging or altered circulation, then the distribution of bioavailable iron and ligands would be altered. Thus, we carry out a number of sensitivity experiments to test the sensitivity of export production and atmospheric $\mathrm{CO}_{2}$ to the values chosen for ligand strength and concentration.

\section{Model Formulation}

\subsection{Physical Model}

[16] The Bern3D ocean circulation model [Müller et al., 2006] is based on the three-dimensional rigid lid ocean model of Edwards et al. [1998] and Edwards and Marsh [2005]. It has a horizontal resolution of $36 \times 36$ grid boxes and 32 layers in the vertical, spaced logarithmically ranging from $39 \mathrm{~m}$ in the uppermost layer to $397 \mathrm{~m}$ for the deepest layer. The model has been tuned toward observed chlorofluorocarbon inventories as well as deep ocean radiocarbon signatures. Model results are found to be consistent with observed large-scale distributions of a wide range of tracers [Müller et al., 2006]. The physical model is forced with seasonal climatologies for wind stress and temperature, and seasonal, long-term averaged salinity fluxes diagnosed at the end of the spin-up phase during which salinity is restored toward climatological values as described by Müller et al. [2008]. Despite the coarse resolution, the model is able to capture the broad scale circulation of the world's ocean (Figure 3), although the formation of and propagation of North Atlantic Deep Water is too weak and convection in the Southern Ocean is too vigorous in the version of the model used for this study. The model's adequate representation of dynamics and inclusion of seasonality coupled to its fast integration time makes it ideal for carrying out millennial-scale paleoclimatic simulations, as well as sensitivity studies in short periods of time.

\subsection{Biogeochemical Model}

[17] The biogeochemical model of the Ocean Carbon Cycle Intercomparison Project (OCMIP-II [Najjar et al., 2007]) as implemented by Müller et al. [2008] is modified by adding the iron cycle and a prognostic formulation of biological productivity in the euphotic zone. Biological tracers in the model include phosphate $\left(\mathrm{PO}_{4}\right)$, dissolved organic phosphorus (DOP), dissolved inorganic carbon (DIC), alkalinity, dissolved oxygen $\left(\mathrm{O}_{2}\right)$ and dissolved iron $\left(\mathrm{Fe}_{T}\right)$. Although silicic acid can be a very important limiting element, at the time of these simulations, the silicon cycle had not been added to the model. The tracers are transported by the modeled circulation, convection and mixing processes.

[18] The biological consumption of phosphate is limited by the availability of $\mathrm{Fe}$ or $\mathrm{PO}_{4}$ and light parameterized following Doney et al. [2006] as

$$
\Gamma=\left(F_{T} \cdot F_{N} \cdot F_{I} \cdot B\right) / \tau, \text { for } z>z_{\text {euph }}
$$

$F_{T}$ represents temperature limitation, $F_{N}$ nutrient limitation due to Michaelis-Menten dynamics, $F_{I}$ solar irradiance limitation, $B$ biomass concentration, while $\tau$ represents the uptake time scale (30 days). A fraction, $\sigma=0.67$, of productivity, $\Gamma$, enters the dissolved organic pool, which has an $e$-folding time scale for remineralization of 6 months [Archer et al., 1997; Yamanaka and Tajika, 1997]. The remaining fraction of consumed nutrients, $(1-\sigma) \Gamma$, is instantaneously exported as particulate to depth where it is remineralized according to the empirical power law relationship determined by Martin et al. [1987]. Any remaining particulate organic matter that reaches the bottom of the model domain is instantly remineralized. The ocean carbon cycle model is coupled to a simple, well-mixed atmospheric reservoir of $\mathrm{CO}_{2}$. Carbonate chemistry is solved in accordance with OCMIP-III protocols and the air-sea gas exchange of carbon dioxide and oxygen is implemented according to the OCMIP-II protocols.

[19] The oceanic cycle of iron is explicitly represented in our model following Parekh et al. [2004, 2005] with minor 

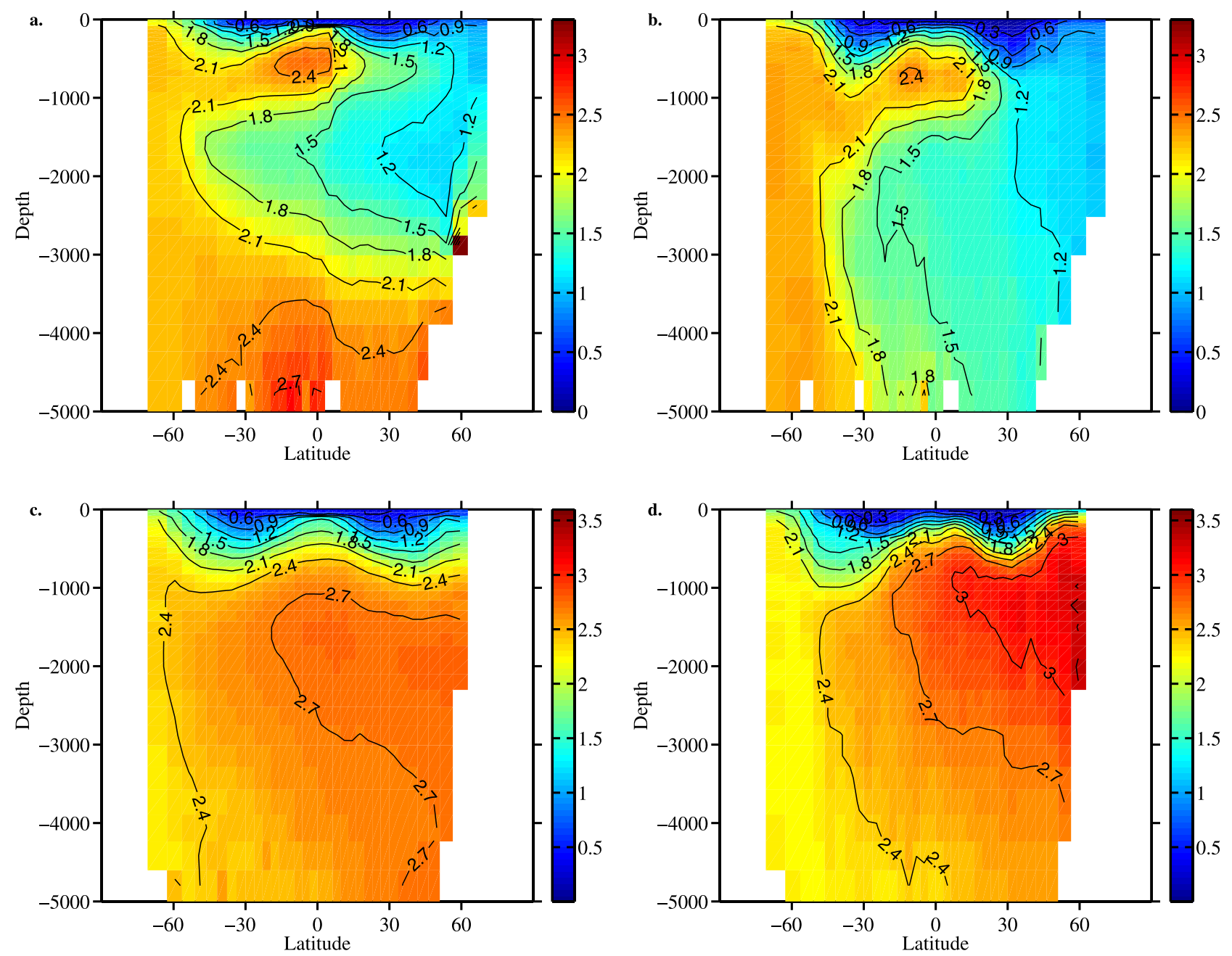

Figure 4. (a) Modeled and (b) observed zonal annual mean meridional transect of $\mathrm{PO}_{4}$ in the Atlantic. (c) Modeled and (d) observed zonal annual mean meridional transect of $\mathrm{PO}_{4}$ in the Pacific. Units are $\mu \mathrm{M}$. Observations are taken from the NOAA Global Ocean Atlas [Conkright et al., 2002].

modifications and additions. Upwelled iron is an important internal source of Fe to surface waters. External sources of iron in the model include aeolian deposition and continental margin sediments. The aeolian source is based on modeled estimates of monthly dust flux generated from an atmospheric transport model [Luo et al., 2003] with an assumed uniform solubility of $1 \%$. Similar to Moore et al. [2004], we apply a constant iron sedimentary flux of $1 \mu \mathrm{mol} \mathrm{Fe} \mathrm{m}{ }^{-2} \mathrm{~d}^{-1}$ for areas where the shelf depth is less than $1100 \mathrm{~m}$. It is assumed that dissolved iron $(\mathrm{Fe})$ is partitioned into free, $\mathrm{Fe}^{\prime}$, and complexed, FeL, forms [Parekh et al., 2004]. Although a consensus is emerging that two classes of ligands exist in the modern ocean, only one ligand class is modeled because of large uncertainties in ligand properties. A spatially uniform concentration of total organic ligand, L, is imposed and can also partition into free and complexed forms. We assume rapid thermodynamic equilibration [Witter et al., 2000], governed by the relation $K_{F e L}=[\mathrm{FeL}] /\left(\left[\mathrm{Fe}^{\prime}\right]\left[\mathrm{L}^{\prime}\right]\right)$, where the conditional stability coefficient, $\log _{10}\left(K_{F e L}\right)=11$, lies within the range estimated from laboratory and field studies. The conditional stability coefficient has been tuned to the modern distributions of $\mathrm{Fe}$ and $\mathrm{PO}_{4}$ for a ligand concentration of $1 \mathrm{nM}$. This results in a modern iron distribution that is in general agreement with observations of iron and excess ligand concentrations [Parekh et al., 2004; 2005, see section 3.3]. Increasing (decreasing) ligand concentration results in more (less) bioavailable iron and fewer (more) regions being iron limited. In turn, productivity and atmospheric $\mathrm{CO}_{2}$ react less (more) sensitively to changes in aeolian iron. In this model, the total iron pool $(\mathrm{Fe})$ is available for biological consumption, but only $\mathrm{Fe}^{\prime}$ is susceptible to scavenging, whose rate is dependent on the local particle concentration and $\mathrm{Fe}^{\prime}$ [Parekh et al., 2005]. Thus scavenging is more efficient in the upper water column, i.e., biologically active regions of the ocean.

\subsection{Mean State}

[20] The model biogeochemistry was integrated for 5,000 years under preindustrial conditions with atmospheric $\mathrm{CO}_{2}$ 

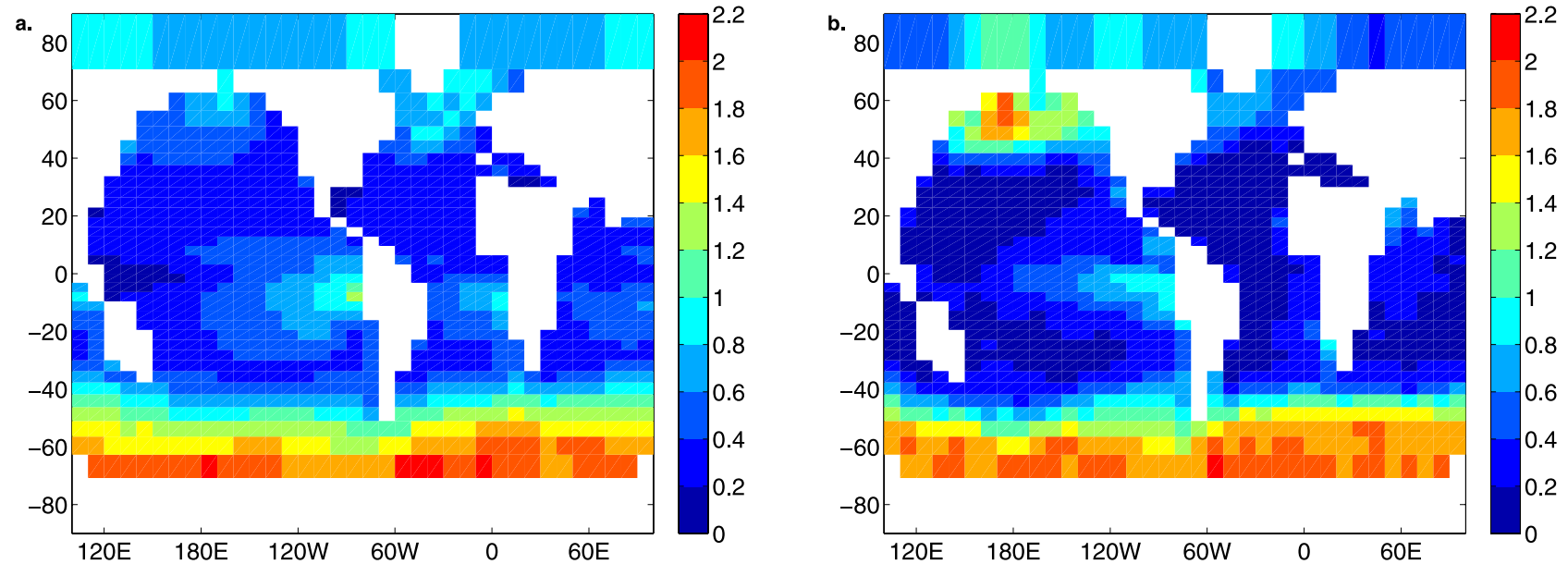

Figure 5. Annually averaged surface $\left[\mathrm{PO}_{4}\right](\mu \mathrm{M})$ predicted by (a) the model compared to (b) observations from NOAA Global Ocean Atlas [Conkright et al., 2002].

held constant at 278 ppmv. Here we discuss the resulting $\mathrm{PO}_{4}$ and $\mathrm{Fe}$ fields and export production.

\subsubsection{Phosphorus}

[21] Figure 4 compares the zonally averaged modeled and observed distributions of phosphate in the Atlantic and Pacific. The model is able to broadly capture the deep water and interbasinal gradients. Phosphate concentrations are too high in the deep Atlantic, because of the weak North Atlantic Deep Water formation in the model. Because of iron and light limitation, surface $\mathrm{PO}_{4}$ concentrations are elevated in HNLC regions (Figure 5). In reality silicic acid also limits productivity, but it is not included in our model. While modeled $\left[\mathrm{PO}_{4}\right]$ are above zero in the North Pacific, they are lower than observations. This discrepancy can be attributed to weaknesses in the model physics which is also found in more complex general circulation models [Aumont and Bopp, 2006; Gnanadesikan et al., 2002, 2004]. The model has some difficulty distinguishing the HNLC equatorial region from the low $\mathrm{PO}_{4}$ region of the subtropical gyres. Some of the upwelled $\mathrm{PO}_{4}$ is transported to the subtropics resulting in high modeled $\left[\mathrm{PO}_{4}\right]$ in this region.

\subsubsection{Iron}

[22] We compare the modeled annual mean iron distribution at the surface (Figure 6) and at $1200 \mathrm{~m}$ (Figure 7) to observations compiled by Parekh et al. [2005] and updated by Moore and Braucher [2008]. Surface concentrations are highest in the North Atlantic and North Indian because of proximity to aeolian sources, the main input of iron into the ocean. The central Pacific and South Atlantic are characterized by low surface concentrations. Though observations are sparse, the model appears to overpredict surface iron concentrations in the Southern Ocean and the North Pacific. In general the model tends to overpredict surface iron
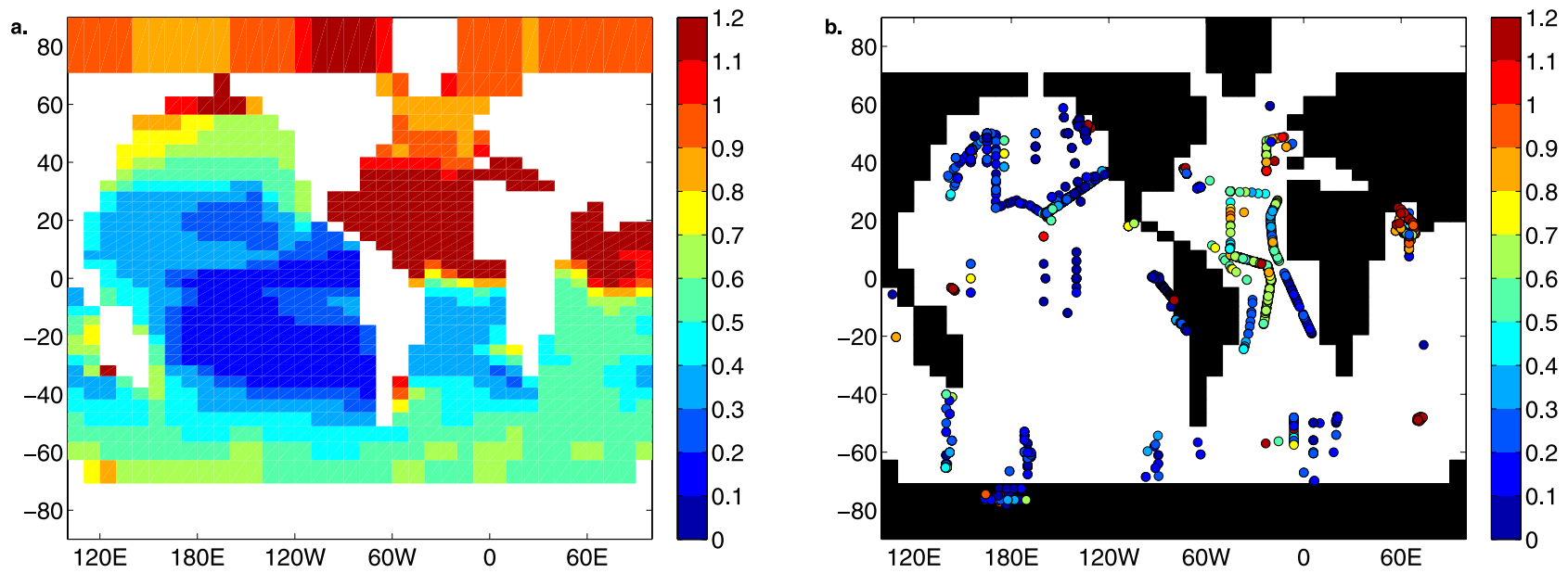

Figure 6. (a) Annually averaged modeled surface Fe (nM). (b) Observed iron concentrations compiled by Parekh et al. [2005] and updated by Moore and Braucher [2008]. 

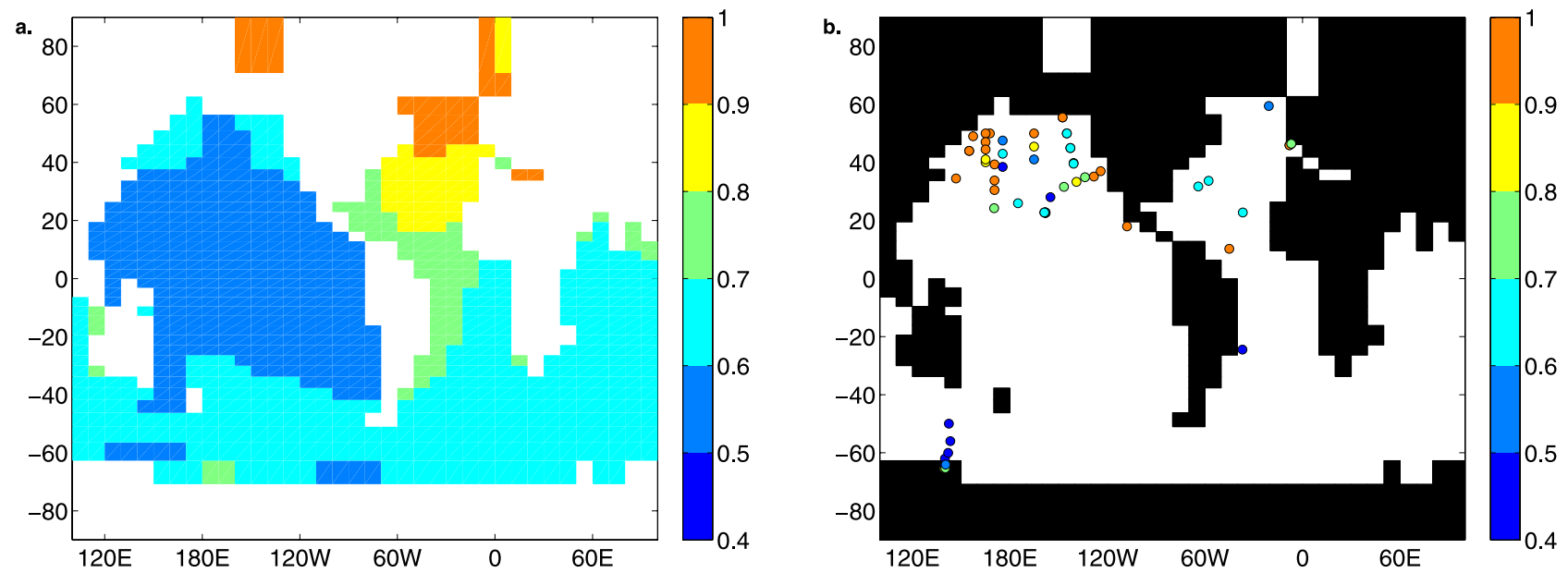

Figure 7. (a) Annually averaged modeled $\mathrm{Fe}(\mathrm{nM})$ at $1200 \mathrm{~m}$. (b) Observed iron concentrations compiled by Parekh et al. [2005] and updated by Moore and Braucher [2008].

concentrations, but is able to capture the general pattern. At $1200 \mathrm{~m}$, concentrations are highest in the North Atlantic waters (Figure 7). The model appears to overpredict iron concentrations in the Southern Ocean and the North Atlantic compared to the sparse observations, but the model is able to capture elevated concentrations in the North Pacific due to the sedimentary source. More iron measurements at depth are necessary in order to better characterize deep water iron gradients.

\subsubsection{Export Production}

[23] Modeled global annual mean export production is 11.1 Gt $\mathrm{C} \mathrm{a}^{-1}$, in good agreement with inverse calculations [Schlitzer, 2000] and satellite-derived estimates [Laws et al., 2000]. Modeled export production is highest in the Southern Ocean (Figure 8). In the North Pacific, modeled export is much lower than estimates because of the difficulty of representing ocean dynamics in this region under such coarse resolution conditions. Modeled export production is also lower in eastern coastal upwelling regions than estimates suggest. Although an ecosystem model is not included, the model results compare well with those that do [Moore et al., 2004; Dutkiewicz et al., 2005; Aumont and Bopp, 2006].

\section{Model Results}

\subsection{Sensitivity to Elevated Iron Fluxes}

[24] We perform a series of sensitivity studies to assess which regions are responsible for the aeolian-induced drawdown of carbon dioxide and how the $\mathrm{CO}_{2}$ response depends on the magnitude of the additional dust flux. The ocean is divided into 8 regions and dust flux is increased 100 -fold for 1000 years in each region, while holding dust deposition constant in the other regions (Table 1). Thereafter, the model is close to having reached a new steady state.

[25] The largest response is in the Southern Ocean with a drawdown in atmospheric $\mathrm{CO}_{2}$ of 10 ppmv, a decrease in the amount of $\mathrm{PO}_{4}$ in the euphotic zone by $10 \%$ and an increase in particulate export production of $0.4 \mathrm{Gt} \mathrm{C} \mathrm{a}^{-1}$
(Table 1). Since the Southern Ocean has the highest concentration of surface macronutrients (Figure 5), it is not surprising that the biological response is strongest in this region.

[26] Increasing iron deposition in the equatorial and North Pacific results in atmospheric $\mathrm{CO}_{2}$ decreasing by only 3 ppmv and 0.7 ppmv, respectively, in agreement with other model studies [Sarmiento and Orr, 1991; Aumont and Bopp, 2006]. These two regions are not directly connected to the deep ocean through convection and deep water formation. Therefore a small impact on atmospheric $\mathrm{CO}_{2}$ is expected because of additional iron input.

[27] There is a response to iron fertilization in the South Pacific and the Indian Ocean, although they are not iron limited regions. In the case of the Indian Ocean, atmospheric $\mathrm{CO}_{2}$ decreases by 2 ppmv, but export production does not

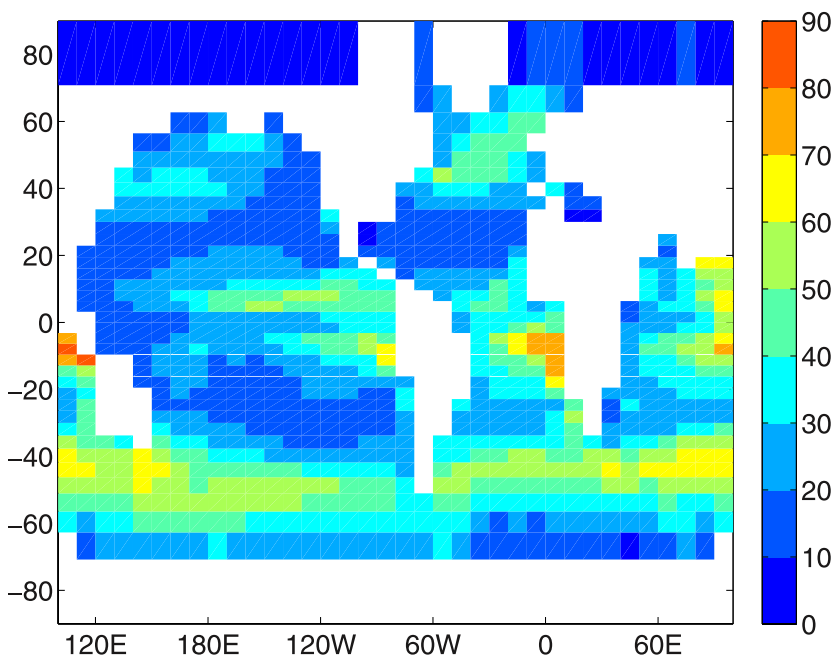

Figure 8. Annually averaged modeled export production $\left(\mathrm{g} \mathrm{C} \mathrm{m}^{-2} \mathrm{a}^{-1}\right)$. Global export production is $11.1 \mathrm{Gt} \mathrm{C} \mathrm{a}^{-1}$. 
Table 1. Summary of Elevated Iron Flux Simulations

\begin{tabular}{|c|c|c|c|c|}
\hline Regions & Latitude & Longitude & $\Delta$ Atmospheric $\mathrm{CO}_{2}$ (ppmv) & $\Delta$ Export $\left({\left.\mathrm{Gt} \mathrm{C} \mathrm{a}^{-1}\right)}^{-1}\right.$ \\
\hline Equatorial Atlantic & $6^{\circ} \mathrm{N}$ to $6^{\circ} \mathrm{S}$ & $60^{\circ} \mathrm{W}$ to $10^{\circ} \mathrm{E}$ & -0.2 & 0.01 \\
\hline Equatorial Pacific & $6^{\circ} \mathrm{N}$ to $6^{\circ} \mathrm{S}$ & $80^{\circ} \mathrm{W}$ to $120^{\circ} \mathrm{E}$ & -2.9 & 0.19 \\
\hline Indian Ocean & $34^{\circ} \mathrm{S}$ to $30.5^{\circ} \mathrm{N}$ & $30^{\circ} \mathrm{E}$ to $150^{\circ} \mathrm{E}$ & -2 & 0.13 \\
\hline North Atlantic & $19.5^{\circ} \mathrm{N}$ to $63^{\circ} \mathrm{N}$ & $10^{\circ} \mathrm{W}$ to $100^{\circ} \mathrm{W}$ & 0 & 0 \\
\hline North Pacific & $34^{\circ} \mathrm{N}$ to $63^{\circ} \mathrm{N}$ & $120^{\circ} \mathrm{W}$ to $130^{\circ} \mathrm{E}$ & -0.7 & 0.05 \\
\hline South Atlantic & $6^{\circ} \mathrm{S}$ to $38^{\circ} \mathrm{S}$ & $60^{\circ} \mathrm{W}$ to $20^{\circ} \mathrm{E}$ & -0.5 & 0.04 \\
\hline South Pacific & $6^{\circ} \mathrm{S}$ to $19.5^{\circ} \mathrm{S}$ & $80^{\circ} \mathrm{W}$ to $140^{\circ} \mathrm{E}$ & -3.4 & 0.21 \\
\hline Southern Ocean & $42^{\circ} \mathrm{S}$ to $77^{\circ} \mathrm{S}$ & all longitudes & -10 & 0.44 \\
\hline Global & all latitudes & all longitudes & -10 & 0.45 \\
\hline No light limitation & all latitudes & all longitudes & -30.5 & 2.07 \\
\hline No light limitation + global & all latitudes & all longitudes & -43 & 2.59 \\
\hline Parameter Perturbed & Original Value & New Value & $\Delta$ Atmospheric $\mathrm{CO}_{2}(\mathrm{ppmv})$ & $\Delta$ Export $\left(\mathrm{Gt}^{\left.\mathrm{C} \mathrm{a}^{-1}\right)}\right.$ \\
\hline Ligand concentration $([L])$ & $1 \mathrm{nM}$ & $2 \mathrm{nM}$ & -10 & 0.48 \\
\hline $\begin{array}{l}\text { Ligand concentration }([L]) \\
\quad+100 \times \text { dust Southern Ocean }\end{array}$ & $1 \mathrm{nM}$ & $2 \mathrm{nM}$ & -10 & 0.48 \\
\hline Ligand concentration $([L])$ & $1 \mathrm{nM}$ & $0.6 \mathrm{nM}$ & +22 & -1.63 \\
\hline $\begin{array}{l}\text { Ligand concentration }([L]) \\
\quad+100 \times \text { dust Southern Ocean }\end{array}$ & $1 \mathrm{nM}$ & $0.6 \mathrm{nM}$ & -3 & -0.03 \\
\hline $\begin{array}{l}\text { Ligand conditional stability } \\
\text { constant }\left(\log \left(\mathrm{K}_{F e L}\right)\right)\end{array}$ & 11 & 14 & -8 & 0.42 \\
\hline $\log \left(\mathrm{K}_{F e L}\right)+100 \times$ dust Southern Ocean & 11 & 14 & -10 & 0.49 \\
\hline $\begin{array}{l}\text { Ligand conditional stability } \\
\text { constant }\left(\log \left(\mathrm{K}_{F e L}\right)\right)\end{array}$ & 11 & 9 & +91 & -6.36 \\
\hline $\log \left(\mathrm{K}_{F e L}\right)+100 \times$ dust Southern Ocean & 11 & 9 & +43 & -4.57 \\
\hline
\end{tabular}

change relative to the control in the Indian Ocean (Figure 9). Instead the Fe added to the Indian Ocean is transported to the Southern Ocean, partially alleviating iron limitation there. In the case of the South Pacific, $\mathrm{CO}_{2}$ decreases by 3.4 ppmv with export production increasing in the $\mathrm{S}$. equatorial Pacific and the Southern Ocean. The S. Pacific is partially ironlimited in the model and therefore responds to the increased

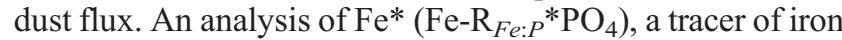
limitation [Parekh et al., 2005], reveals that seeding the South Pacific and Indian Ocean results in the area of iron limitation being pushed southward by approximately $5^{\circ}$ in the Southern Ocean because of lateral transport of Fe. Therefore, similar to Lefévre and Watson [1999] we conclude that transport of iron from other regions into the Southern Ocean can be an important source of iron.

[28] Because of the input of Fe from the Sahara, the Atlantic basin is not considered Fe limited. Thus seeding the Atlantic has almost no effect on atmospheric $\mathrm{CO}_{2}$, phosphate drawdown, or export production and does not partially alleviate iron limitation in the Southern Ocean because the transport time between the Atlantic and the Southern Ocean is longer than the time scale for scavenging in the model. By the time NADW reaches the Southern Ocean, most of the iron has been lost because of scavenging.

[29] We also increase aeolian iron deposition 100 fold everywhere within the model domain over 1000 years. Atmospheric carbon dioxide decreases by $10 \mathrm{ppmv}$ and particulate export production increases by $0.45 \mathrm{Gt} \mathrm{C} \mathrm{a} \mathrm{a}^{-1}$, almost the same response as the Southern Ocean only case (Table 1). The only difference in the pattern of export production between the two cases is that export production is slightly higher in the equatorial Pacific in the global case. Thus, the Southern Ocean is responsible for the bulk of the response in the global case. Even though iron input into the
Southern Ocean has increased in the global case (because of transport of iron from the Indian and S. Pacific), the biological response does not.

[30] We test the sensitivity of atmospheric $\mathrm{CO}_{2}$ to the magnitude of dust flux deposited to the Southern Ocean. We adjusted the relative dust loading in the Southern Ocean and found that atmospheric $\mathrm{CO}_{2}$ changes do not respond linearly to relative changes in dust loading (Figure 10a). The response of atmospheric $\mathrm{CO}_{2}$ to dust loading asymptotes. At a certain point the efficiency of iron fertilization decreases. Thus, our results suggest there is an upper limit

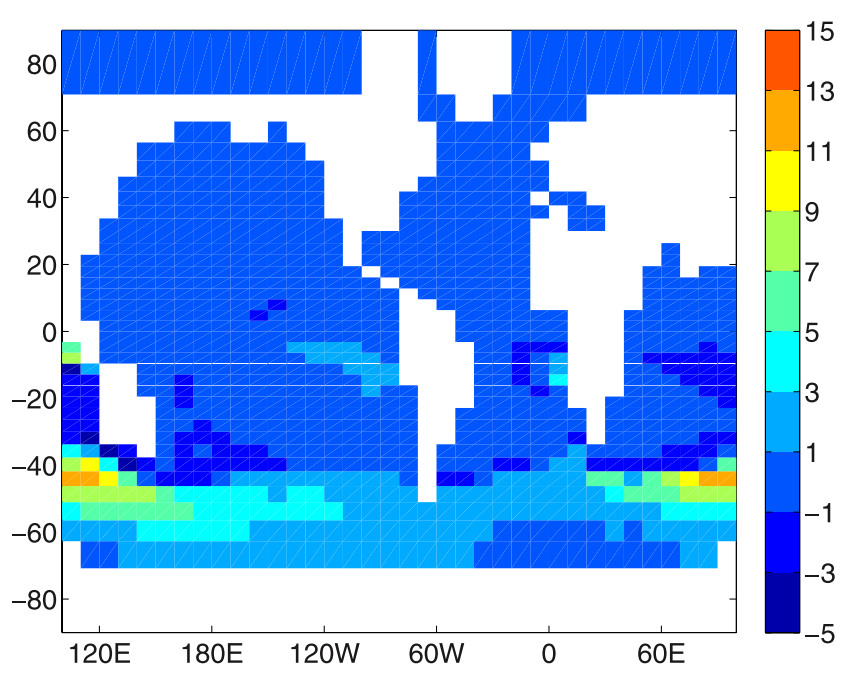

Figure 9. Differences in annually averaged export production between the perturbed and control run $\left(\mathrm{g} \mathrm{C} \mathrm{m}^{-2} \mathrm{a}^{-1}\right)$ for the Indian Ocean. 

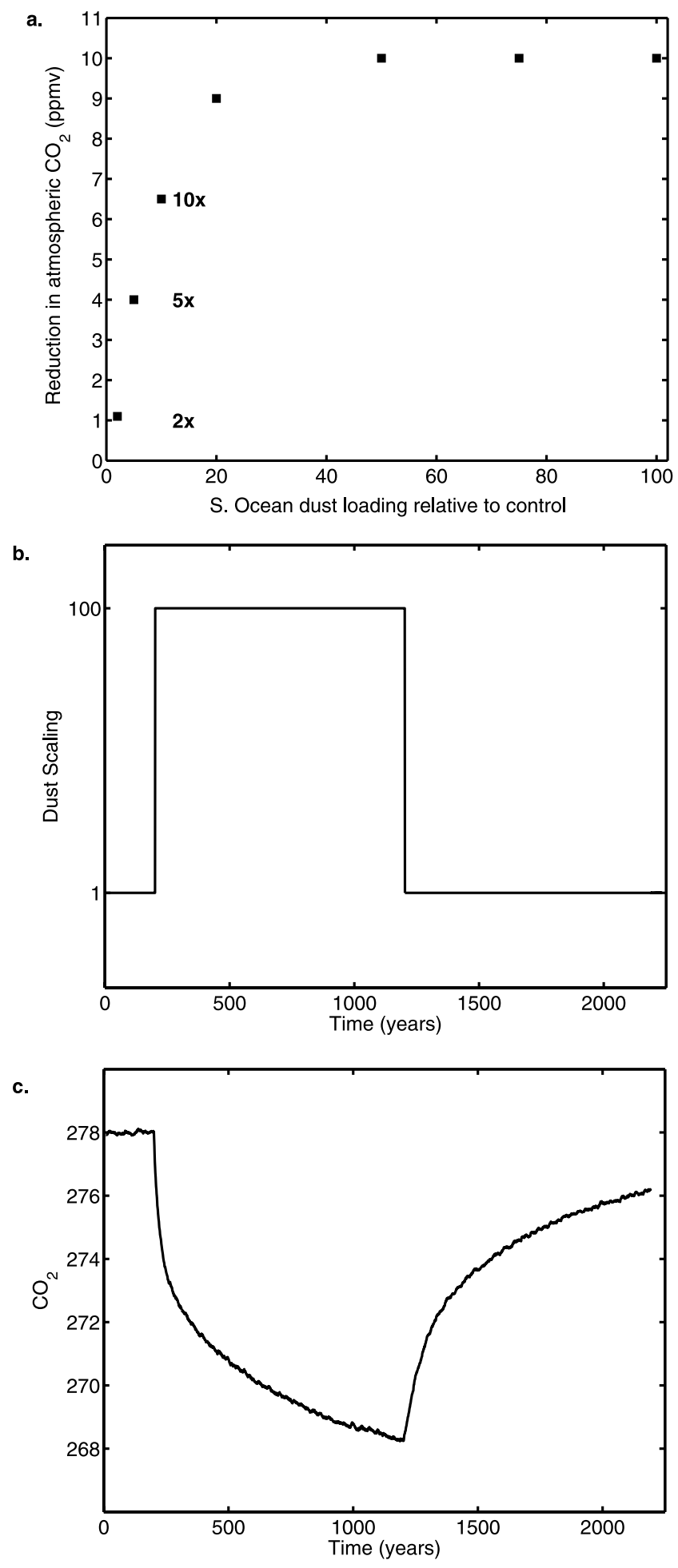

Figure 10. (a) Sensitivity of modeled atmospheric $\mathrm{CO}_{2}$ to aeolian flux. The reduction in atmospheric $\mathrm{CO}_{2}$ (ppmv) is relative to the modern control after 1000 years with modified dust source in the Southern Ocean. Time evolution of (b) dust flux forcing and (c) $\mathrm{CO}_{2}$ for a 100-fold increase in the Southern Ocean. to iron response. Once that limit is reached, it is not possible to further increase export production and decrease atmospheric $\mathrm{CO}_{2}$, even though the phosphate inventory in the euphotic zone has only decreased by $10 \%$. This implies that there are additional factors limiting productivity in the Southern Ocean. We also show the time evolution of $\mathrm{CO}_{2}$ when the model is forced with a 100fold increase in dust over 1000 years in the Southern Ocean and the response of $\mathrm{CO}_{2}$ when the dust flux returns to normal (Figures $10 \mathrm{~b}$ and $10 \mathrm{c}$ ). $\mathrm{CO}_{2}$ decreases sharply within the first 100 years because of the sudden increase in aeolian iron. Thereafter, $\mathrm{CO}_{2}$ decreases slowly since iron limitation is not strong as initially. Decreasing dust flux results in an initial rapid increase in $\mathrm{CO}_{2}$, and eventually a new steady state is reached.

[31] Field studies show that light and silicic acid also control productivity in the Southern Ocean [Boyd, 2002; Smith and Lancelot, 2004]. Our model does not include the silicon cycle, thus we cannot test the influence of silicic acid on productivity. But, we perform a sensitivity study to quantify the control light places on atmospheric $\mathrm{CO}_{2}$, export production and surface macronutrient concentrations. We remove light limitation by setting $F_{I}=1$ in equation (1) globally. Such a situation is not realistic, but it makes it possible to quantify the potential of light to limit oceanic productivity. Atmospheric $\mathrm{CO}_{2}$ decreases to $247.5 \mathrm{ppmv}$, export production increases by $2.07 \mathrm{Gt} \mathrm{C} \mathrm{a}^{-1}$ and $\left[\mathrm{PO}_{4}\right]$ decreases by $30 \%$ in the euphotic zone. Adding excess dust globally results in atmospheric $\mathrm{CO}_{2}$ dropping another 12.5 ppmv to 235 ppmv and $\left[\mathrm{PO}_{4}\right]$ decrease another $10 \%$. Light appears to be a stronger control than iron [Popova et al., 2000; Dutkiewicz et al., 2005; Aumont and Bopp, 2006]. Despite the removal of light and iron limitation, surface $\mathrm{PO}_{4}$ remains elevated in the Southern Ocean. Similar to Aumont and Bopp [2006], we attribute this to convection. The Bern3D model in the preindustrial steady state is characterized by deep convection cells in the Southern Ocean that are constantly bringing up nutrient rich waters.

\subsection{Sensitivity to Ligand Concentration and Strength}

[32] The values used for the ligand strength and concentration in the model are within the wide range of limited measurements and are tuned toward observed oceanic iron concentrations. Yet during other climatic periods, the strength and concentration of the ligand could have been different. For example, ligand production has been observed to increase in response to mesoscale iron additions in the Pacific and Southern Oceans [Rue and Bruland, 1997; Croot et al., 2001; Boye et al., 2005]. Thus, it is plausible that during the LGM, when aeolian iron inputs were higher, ambient ligand concentration was also higher in the ocean. Although the ligand concentration is spatially constant in the model, we know that this is not the case in the real ocean. Perhaps ligand concentrations are higher in regions that receive higher external iron inputs such as the North Atlantic. It is also assumed in the model that the ligand strength is constant throughout the ocean, although this is not the case in the real ocean. A review of trace metal data for $\mathrm{Cd}, \mathrm{Cu}, \mathrm{Pb}$ and $\mathrm{Zn}$ has suggested that a wide spectrum 


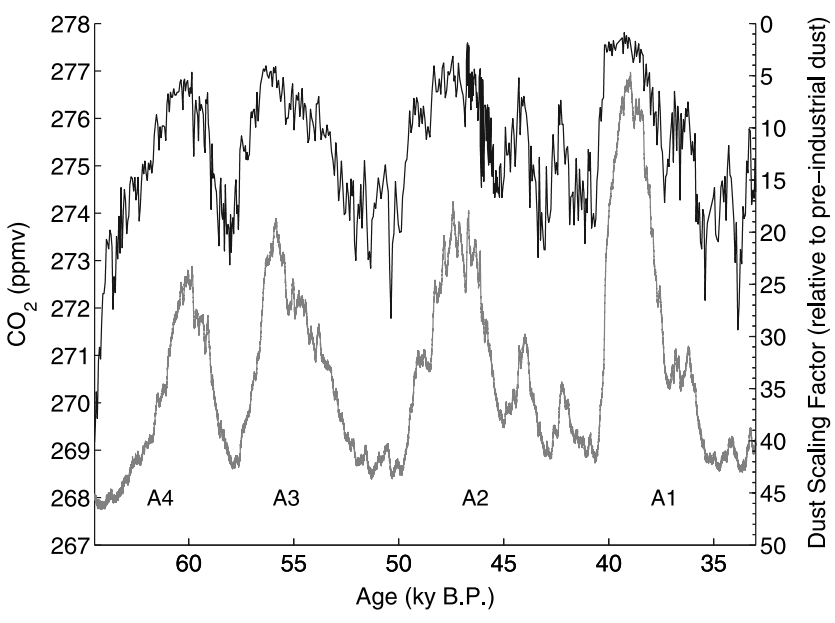

Figure 11. Dust scaling factor (black curve) and modeled atmospheric $\mathrm{CO}_{2}$ (gray curve) plotted against time ( $\mathrm{SS} 09$ sea time scale is applied to the data). Note that the $y$ axis of the dust scaling factor is reversed.

of ligand strengths could explain the linear relationship between conditional stability constant and ligand concentration [Town and Filella, 2000]. The same could hold true for Fe since existing measurement methods are not capable of resolving more than one or two ligand classes [Hunter and Boyd, 2007]. Furthermore, the ligand strength could also change during geological time. While we lack enough knowledge to parameterize what controls ligand strength and concentration in the ocean, we can carry out sensitivity studies to assess how a change in ligand strength and concentration affects atmospheric $\mathrm{CO}_{2}$ concentrations or surface nutrient concentrations. Such studies give us insight on the potential role the iron cycle could have or will play during times of altered iron input.

[33] We adjust the [L] in the control case within the range observed in the ocean today. Doubling ligand concentration from $1 \mathrm{nM}$ to $2 \mathrm{nM}$ in the control case results in $\mathrm{CO}_{2}$ decreasing by $10 \mathrm{ppmv}$ and $\left[\mathrm{PO}_{4}\right]$ decreasing in the euphotic zone by $10 \%$ (Table 1). Increasing dust flux in the Southern Ocean for this case (doubled ligand concentration) does not decrease atmospheric $\mathrm{CO}_{2}$ further. The degree of iron limitation is less than the control case and other factors such as light play a more important role. Interestingly, decreased ligand concentration, coupled with increased dust flux has a much larger effect. Decreasing ligand concentration to $0.6 \mathrm{nM}$ results in $\mathrm{CO}_{2}$ increasing by 22 ppmv to 300 ppmv (Table 1), with a $40 \%$ increase in the amount of $\mathrm{PO}_{4}$ in the euphotic zone and iron limitation spreading to all regions except the North Atlantic. When this change in ligand concentration is coupled to increased dust flux in the Southern Ocean, atmospheric carbon dioxide drops to $275 \mathrm{ppmv}$, which means that the increase in dust flux counteracts the effects of decreasing ligand strength. The response is so strong because decreasing ligand concentration results in a greater degree of iron limitation in the model. Thus the addition of iron has a larger effect.
[34] We also test the sensitivity of $\mathrm{CO}_{2}$ to changing the strength of the ligand within the range of values observed in the modern ocean for the conditional stability constant. Increasing the stability constant from $10^{11}$ to $10^{14} \mathrm{M}^{-1}$ results in a drop of 8 ppmv and $9 \%$ less $\mathrm{PO}_{4}$ in the euphotic zone. Increasing dust flux 100-fold over the Southern Ocean results in only another $2 \mathrm{ppmv}$ (Table 1). Decreasing the ligand strength to $10^{9} \mathrm{M}^{-1}$ results in an increase in atmospheric $\mathrm{CO}_{2}$ from 278 ppmv to 369 ppmv, while $\mathrm{PO}_{4}$ increases 2.5 times in the euphotic zone. Increased dust flux in the Southern Ocean brings atmospheric $\mathrm{CO}_{2}$ down another $35 \mathrm{ppmv}$ (Table 1). Similar to the simulation, in which we change the magnitude of the ligand concentration, decreasing ligand strength increases iron limitation in the model. An addition of iron thus has a larger effect.

\subsection{Dome C Dust Record}

[35] Changes in circulation strength causing a release of carbon from the ocean [Marchal et al., 1999] and land [Köhler et al., 2005; Scholze et al., 2003] and variations in dust loading to the Southern Ocean [Röthlisberger et al., 2004] have been put forth as possible explanations for the $20 \mathrm{ppmv}$ variations in $\mathrm{CO}_{2}$ observed during the Antarctic glacial warm events, A1 to A4 (Figure 2). Since our sensitivity studies demonstrate that atmospheric $\mathrm{CO}_{2}$ is sensitive to variations in aeolian iron flux in the Southern Ocean, we use ice core data to reconstruct dust flux during the A1 to A4 events to quantify the impact it has on $\mathrm{CO}_{2}$.

[36] The model is forced in the Southern Ocean with an estimate of dust flux based on the nss- $\mathrm{Ca}^{2+}$ record from Dome C between 64.5 and 33 ka B.P. The SS09sea age scale is applied to the nss-Ca ${ }^{2+}$ data. In order to calculate dust flux from the data, we divide the nss- $\mathrm{Ca}^{2+}$ flux between 64.5 and 33 ka B.P by the preindustrial nss- $\mathrm{Ca}^{2+}$ flux at Dome $\mathrm{C}$ to get a dust scaling factor. We then multiply the control dust forcing of the model in the Southern Ocean by this scaling factor. The model is run under preindustrial conditions with atmospheric $\mathrm{CO}_{2}$ tuned to $278 \mathrm{ppmv}$ and is initially forced with the mean dust scaling factor for 1000 years resulting in a drop of atmospheric $\mathrm{CO}_{2}$ by 8 ppmv. Thereafter the model is forced with the scaled dust flux from 64.5 to $33 \mathrm{ka} \mathrm{B.P.}$

[37] The model results clearly show that $\mathrm{CO}_{2}$ responds to changes in dust flux inversely (Figure 11). For example, during A1, dust flux is lowest over the course of our simulation, resulting in the highest modeled concentration of atmospheric $\mathrm{CO}_{2}$. After the $\mathrm{A} 1$ event, dust flux increases again and $\mathrm{CO}_{2}$ drops. The magnitude of $\mathrm{CO}_{2}$ fluctuations are smaller than those observed [Indermühle et al., 2000] (Figure 12, black curve). There is a lag in the response of $\mathrm{CO}_{2}$ ranging between 500 to 1800 years in our model results (Figure 11). From the results of our simulation, in which we analyze the time evolution of $\mathrm{CO}_{2}$ for an increased dust flux event in the Southern Ocean (Figure 10c), we expect there to be a lag when dust flux is increased. It is not clear why there is also a lag in the modeled $\mathrm{CO}_{2}$ during times of decreased dust flux. Similar to the experiments, in which we progressively increased dust flux in the Southern Ocean (Figure 10a), at a certain point, $\mathrm{CO}_{2}$ ceases to respond to increases in dust flux, 


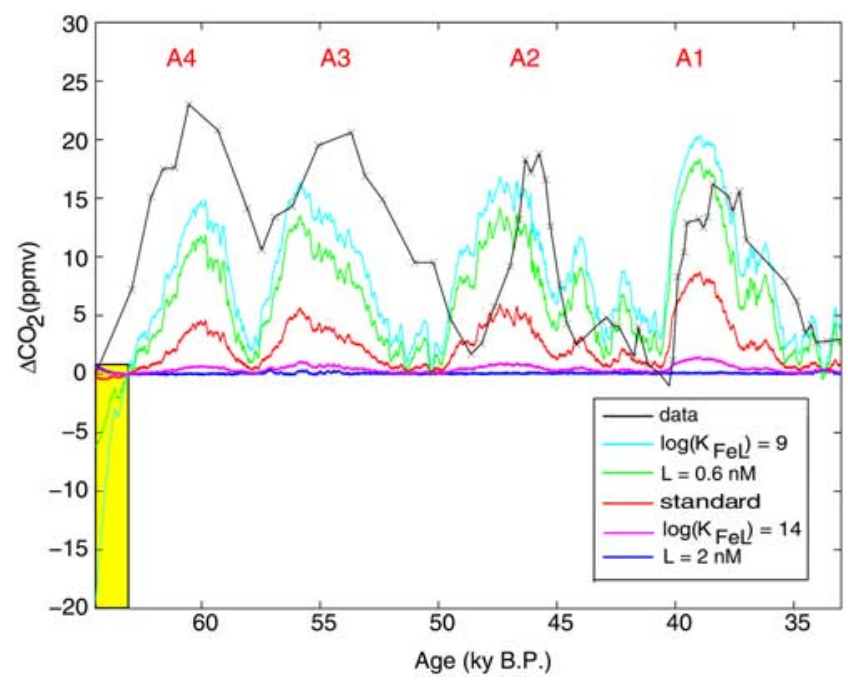

Figure 12. $\Delta$ atmospheric $\mathrm{CO}_{2}$ ice core record from Taylor Dome, Antarctica, plotted against time (SS09sea time scale, black curve). The crosses represent the actual data points. Error in the measurements ranges between 0.2 and $1.1 \mathrm{ppmv}$. $\Delta$ atmospheric $\mathrm{CO}_{2}$ was calculated for the data by subtracting the initial atmospheric $\mathrm{CO}_{2}$ concentration at the start of the simulation at 64.5 ka B.P. Modeled $\Delta$ atmospheric $\mathrm{CO}_{2}$ forced with the dust scaling factor derived from the Dome $\mathrm{C}$, Antarctica, nss-Ca ${ }^{2+}$ record plotted against time for various cases: standard case (red curve), $[\mathrm{L}]=0.6 \mathrm{nM}$ (green curve), $[\mathrm{L}]=2 \mathrm{nM}$ (dark blue curve), $\log \left(\mathrm{K}_{\mathrm{FeL}}\right)=9$ (light blue curve), and $\log \left(\mathrm{K}_{\mathrm{FeL}}\right)=14$ (magenta curve). The $\Delta$ atmospheric $\mathrm{CO}_{2}$ was calculated by subtracting the value of $\mathrm{CO}_{2}$ for each simulation at $63.1 \mathrm{ka}$ B.P., instead of the initial value at the start of the run (64.5 ka B.P.) to allow the model to adjust to the new ligand parameter values. The area within the yellow box represents this adjustment period.

because other factors become limiting. For example, at approximately 50.7, 35.5 and 34 ka B.P., there is a spike in dust input, yet $\mathrm{CO}_{2}$ does not further decrease (Figure 11).

[38] If ambient ligand concentration or strength changes as a function of ambient iron concentrations, the response by the biological pump and subsequently $\mathrm{CO}_{2}$ may also be different. We increase/decrease the ligand strength and concentration (Table 2) while forcing the model with the nss- $-\mathrm{Ca}^{2+}$ to test how sensitive our model results are to our iron parameter values. A decrease in the ligand concentration from $1 \mathrm{nM}$ to $0.6 \mathrm{nM}$ (Figure 12, green curve) or a decrease in the ligand strength from $\log \left(\mathrm{K}_{\mathrm{FeL}}\right)=11$ to 9 (Figure 12, light blue curve) results in larger fluctuations in modeled $\mathrm{CO}_{2}$, in better agreement with the reconstructed amplitudes. The difference in $\mathrm{CO}_{2}$ at Dome $\mathrm{C}$ between the start and peak of the $\mathrm{A} 4$ event is 23 ppmv, with $\mathrm{CO}_{2}$ decreasing by 12 ppmv before rising again during the $\mathrm{A} 3$ event. The modeled atmospheric $\mathrm{CO}_{2}$ rises by approximately $12 \mathrm{ppmv}$ for the decreased ligand concentration case (Figure 12, green curve) and 14 ppmv for the decreased ligand strength case (Figure 12, light blue curve) between $63.1 \mathrm{ka} \mathrm{B.P.} \mathrm{and} \mathrm{the} \mathrm{peak} \mathrm{of} \mathrm{the} \mathrm{A4} \mathrm{event,} \mathrm{while} \mathrm{dropping}$ again by 9 ppmv (green curve) and 11.5 ppmv (light blue curve). This suggests that other processes are keeping $\mathrm{CO}_{2}$ elevated between the A4 and $\mathrm{A} 3$ event despite increased dust flux. The model is able to capture the magnitude and pattern of atmospheric $\mathrm{CO}_{2}$ changes for the $\mathrm{A} 1$ event (Figure 12, green and light blue curves). Increasing ligand concentration or strength removes iron limitation and therefore changing aeolian iron flux has almost no effect (Figure 12, blue and magenta curves, respectively).

[39] Because of the uncertainty regarding synchronicity between the dust proxy record and the $\mathrm{CO}_{2}$ record, we do not compare the exact timing of events between the model results and the observations. The data shows that the peaks in dust flux are progressively decreasing from the $\mathrm{A} 4$ to the $\mathrm{A} 1$ event (Figure 2). Thus, a progressive increase in the peak $\mathrm{CO}_{2}$ concentration and amplitude in $\mathrm{CO}_{2}$ variations for each event are expected, as our model predicts (Figure 11). In contrast, the peak $\mathrm{CO}_{2}$ and the amplitude of the $\mathrm{CO}_{2}$ variations are decreasing in the data (Figure 2). This suggests that there are other mechanisms that are also placing controls on atmospheric $\mathrm{CO}_{2}$ and that there could be negative feedbacks between various mechanisms. A major factor that could affect atmospheric $\mathrm{CO}_{2}$ that we have not considered is changes in oceanic circulation. Model results suggest that a shutdown of the thermohaline circulation caused by freshwater forcing in the Atlantic could result in $\mathrm{CO}_{2}$ rising by $10-15$ ppmv because of the release of carbon from the ocean [Marchal et al., 1999], while release from the land could account for a rise in $\mathrm{CO}_{2}$ by 6 ppmv [Köhler et al., 2005]. The results of Marchal et al. [1999] did include a biotic ocean carbon cycle, but could not account for changes in the carbon cycle due to changes in iron input because it lacked an iron cycle.

[40] Other factors that we have not considered here include the potential readjustment of the ocean's alkalinity budget and the calcite lysocline [Archer et al., 2000] or changes to the oceanic nitrogen inventory [Falkowski et al., 1998]. For example, if the calcite to organic matter rain ratio changed because of changes in export production or the shift of $\mathrm{CaCO}_{3}$ sedimentation from shelves to the deep ocean [Merico et al., 2008] or nitrogen fixation increased because of increased iron input into the ocean, atmospheric $\mathrm{CO}_{2}$ would also respond. However, reconstructed changes in the depth of the lysocline [Broecker and Henderson, 1998] and colimitation of biological production by other factors suggest a limited role for these mechanisms over the period 65 to 30 ka B.P.

\section{Summary and Discussion}

[41] Despite increasing dust flux 100-fold over 1000 years in specific regions and globally, the changes in $\left[\mathrm{PO}_{4}\right]$,

Table 2. Summary of Dome C Simulations

\begin{tabular}{ccl}
\hline Description & Parameter Changed & New Value \\
\hline Dome $\mathrm{C}$ dust forcing & none & \\
Dome C dust forcing & {$[L]$} & $0.6 \mathrm{nM}$ \\
Dome C dust forcing & {$[L]$} & $2 \mathrm{nM}$ \\
Dome C dust forcing & $\mathrm{K}_{F e L}$ & $10^{9} \mathrm{M}^{-1}$ \\
Dome C dust forcing & $\mathrm{K}_{F e L}$ & $10^{14} \mathrm{M}^{-1}$ \\
\hline
\end{tabular}


export production and $\mathrm{CO}_{2}$ are small in our model, since the control iron exerts on the efficiency of the biological pump is weak. Our model predicts a $10 \mathrm{ppmv}$ drawdown in atmospheric $\mathrm{CO}_{2}$ due to the addition of iron in the Southern Ocean, a much weaker response than earlier assessments [Joos et al., 1991; Peng and Broecker, 1991; Sarmiento and Orr, 1991; Kurz and Maier-Reimer, 1993]. These earlier models predicted a much stronger response, because they lacked an iron cycle and assumed that iron fertilization would result in complete drawdown of surface macronutrients.

[42] We find that atmospheric $\mathrm{CO}_{2}$ changes do not respond linearly to relative changes in dust loading. At a certain point, the efficiency of iron fertilization decreases (Figure 10), since iron is not the only control on oceanic export production rates. While not realistic, the complete removal of light limitation spatially and temporally results in a drop in $\mathrm{CO}_{2}$ of 30.5 ppmv (Table 1), while $\mathrm{CO}_{2}$ only decreases by $10 \mathrm{ppmv}$ in response to a global 100 -fold increase in dust over 1000 years. When we remove light and iron limitation from the whole model domain throughout the year, atmospheric $\mathrm{CO}_{2}$ drops by 43 ppmv.

[43] When other regions in the southern hemisphere that are not iron limited, such as the Indian Ocean or South Pacific are seeded, export production is stimulated in the Southern Ocean because of the lateral transport and advection of iron. On the other hand, iron seeded in the iron-replete region of the North Atlantic did not contribute to a response in the Southern Ocean because the transit time from the North Atlantic to the Southern Ocean is longer than the time scale for scavenging in the model. Similar to other model results [Sarmiento and Orr, 1991; Aumont and Bopp, 2006] there is almost no response to iron fertilization in the subarctic Pacific in our model.

[44] In agreement with models that consist of a prognostic representation of iron [Dutkiewicz et al., 2005; Aumont and Bopp, 2006; Parekh et al., 2005, 2006a], our model results suggest that despite the removal of iron limitation, light limitation and mixing in the Southern Ocean prevent the complete utilization of surface macronutrients under preindustrial conditions. Silicate also plays a role in limiting productivity, but we are not able to assess its effect, since our model lacked the silicon cycle. Using a model that consists of an ecosystem model and a similar parameterization of iron to our model, two other studies have estimated the effect of a global increase in dust flux to the biological pump [Dutkiewicz et al., 2005; Aumont and Bopp, 2006]. Dutkiewicz et al. [2005] find that a tenfold increase in dust flux results in a $0.65 \mathrm{Gt} \mathrm{C} \mathrm{a}^{-1}$ increase in export production, a slightly stronger response than our model predicts. On the other hand, Aumont and Bopp [2006] find that $\mathrm{CO}_{2}$ decreases by 33 ppmv, primary

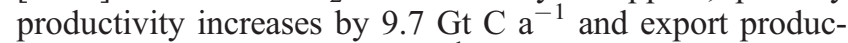
tion increases by $1.8 \mathrm{Gt} \mathrm{C} \mathrm{a}^{-1}$ after fertilizing the global ocean for 100 years forced by fossil fuel emissions from IPCC scenario SRES98-A2. In part, Aumont and Bopp [2006] predict a stronger response because their simulations were forced with modern fossil fuel emissions. We estimate that if we ran our simulation forced by the same fossil fuel emissions, atmospheric $\mathrm{CO}_{2}$ would drop by approximately another $10 \mathrm{ppmv}$ in our simulation. Another reason that our model may predict a weaker response by export production and atmospheric carbon dioxide is due to the lack of an ecosystem model. An ecosystem model is able to account for a change in species' composition, such as a shift toward diatoms which are more effective at transporting carbon to the deep ocean.

[45] Changing parameter values, such as the concentration or the strength of the ligand, can have an effect that is as large or larger than changes in the aeolian dust flux alone. There is an asymmetry in the response when it is coupled to increased dust flux. Decreasing ligand concentration or strength causes atmospheric $\mathrm{CO}_{2}$ to rise. When this change is coupled to dust flux, atmospheric $\mathrm{CO}_{2}$ actually drops below preindustrial levels. Yet, when ligand concentration or strength is increased, atmospheric $\mathrm{CO}_{2}$ decreases, but by only a few ppmv and increasing dust flux has almost no effect. If ligand concentration and/or strength changes in response to changing dust flux, it could imply that a very small dust flux is actually needed to affect $\mathrm{CO}_{2}$ as the primary driver may be the increased strength or concentration of ligand. It is imperative that we increase our knowledge of ligand dynamics to better predict the response of the iron and biological cycle to changing environmental conditions.

[46] The model is forced with the $\mathrm{nss}-\mathrm{Ca}^{2+}$ record, a proxy for dust flux, from Dome $\mathrm{C}$ in the Southern Ocean during the last four warm events (A1 to A4) of the last glacial period. The goal of our study was not to simulate in detail the state of the ocean during the last glacial period, but rather to quantify the effect that changes in aeolian iron flux during the Antarctic glacial warm events have on atmospheric $\mathrm{CO}_{2}$. Depending on the parameter values chosen for ligand concentration and strength, fluctuations in aeolian iron flux can explain a portion of the variation in atmospheric $\mathrm{CO}_{2}$. In the standard case, $\mathrm{CO}_{2}$ varies between 5 and $8 \mathrm{ppmv}$, in the decreased ligand concentration case between 12 and $18 \mathrm{ppmv}$ and in the decreased ligand strength case between 14 and 20 ppmv when forced with the Dome $\mathrm{C} \mathrm{nss- \textrm {Ca } ^ { 2 + }}$ record over the Antarctic glacial warm events. Thus it appears that iron played a minor modulating role and cannot alone account for the full magnitude and evolution of the glacial $\mathrm{CO}_{2}$ fluctuations.

[47] Setting the ligand concentration or strength to a lower value than in the control case results in a greater response by atmospheric $\mathrm{CO}_{2}$ to changing aeolian iron fluxes. If both the concentration or strength are lowered, the change in $\mathrm{CO}_{2}$ would be even more pronounced. It is likely that the ligand concentration responds to ambient iron concentrations [Rue and Bruland, 1997]. Thus, the ligand concentration should decrease when aeolian iron fluxes decrease and vice versa, resulting in a larger drop in atmospheric $\mathrm{CO}_{2}$ when aeolian iron flux increases and a larger rise in atmospheric $\mathrm{CO}_{2}$ when aeolian iron flux decreases, which would better match with the data.

[48] In conclusion, our model results suggest that iron addition to the ocean has a small impact on atmospheric $\mathrm{CO}_{2}$. Thus, commercial schemes proposed to sequester anthropogenic $\mathrm{CO}_{2}$ by iron fertilization of the ocean in 
the context of the Kyoto protocol and greenhouse gas trading schemes may not be effective.

[49] Acknowledgments. P.P. was supported by a Marie Curie International Incoming Fellowship. F.J. would like to acknowledge funding from the Swiss National Foundation. We would like to thank Gian-Kasper Plattner for stimulating discussions and Kuno Strassmann for assistance with figures. We also thank Phil Boyd and an anonymous reviewer for their constructive comments.

\section{References}

Ahn, J., and E. J. Brook (2007), Atmospheric $\mathrm{CO}_{2}$ and climate from 65 to 35 ka B.P., Geophys. Res. Lett., 34, L10703, doi:10.1029/ 2007 GL029551.

Archer, D., and K. Johnson (2000), A model of the iron cycle in the ocean, Global Biogeochem. Cycles, 14, 269-279.

Archer, D., E. Peltzer, and D. Kirchman (1997), A timescale for dissolved organic carbon production in equatorial Pacific surface waters, Global Biogeochem. Cycles, 11, 435-452.

Archer, D., A. Winguth, D. Lea, and N. Mahowald (2000), What caused the glacial/interglacial atmospheric $\mathrm{pCO}_{2}$ cycles?, Rev. Geophys., $38,159-189$.

Aumont, O., and L. Bopp (2006), Globalizing results from ocean in situ iron fertilization studies, Global Biogeochem. Cycles, 20 , GB2017, doi:10.1029/2005GB002591.

Barbeau, K. (2006), Photochemistry of organic iron (III) complexing ligands in oceanic systems, Photochem. Photobiol., 82, 1505-1516.

Barbeau, K., E. L. Rue, K. W. Bruland, and A. Butler (2001), Photochemical cycling of iron in the surface ocean mediated by microbial iron (III)-binding ligands, Nature, 413, 409-413.

Bopp, L., K. Kohfeld, and C. L. Quéré (2003), Dust impact on marine biota and atmospheric $\mathrm{CO}_{2}$, Paleoceanography, 18(2), 1046 , doi:10.1029/2002PA000810.

Boyd, P. W. (2002), Environmental factors controlling phytoplankton processes in the Southern Ocean, J. Physiol., 38, 844-861.

Boyd, P. W., et al. (2000), A mesoscale phytoplankton bloom in the polar Southern Ocean stimulated by iron fertilization, Nature, 407, 695-702.

Boyd, P. W., et al. (2004), The decline and fate of an iron-induced subarctic phytoplankton bloom, Nature, 428, 549-553.

Boye, M., J. Nishioka, P. L. Croot, P. Laan, K. R. Timmermans, and H. J. W. deBaar (2005), Major deviations of iron complexation during 22 days of a mesoscale iron enrichment in the open Southern Ocean, Mar. Chem., 96, $257-271$.

Broecker, W. S., and G. M. Henderson (1998), The sequence of events surrounding Termination II and their implications for the cause of glacial-interglacial $\mathrm{CO}_{2}$ changes, Paleoceanography, 13, 352-364.

Buesseler, K., J. Andrews, S. Pike, and M. Charette (2004), The effects of iron fertilization on carbon sequestration in the Southern Ocean, Science, 304, 414-417.

Charette, M., and K. Buesseler (2000), Does iron fertilization lead to rapid carbon export in the Southern Ocean?, Geochem. Geophys. Geosyst., l(1), 1041, doi:10.1029/2000GC000069.

Coale, K., et al. (1996), A massive phytoplankton bloom induced by an ecosystem-scale iron fertilization experiment in the equatorial Pacific Ocean, Nature, 383, 495-501.

Coale, K., et al. (2004), Southern Ocean iron enrichment experiment: Carbon cycling in highand low-Si waters, Science, 304, 408-414.
Conkright, M., H. E. Garcia, T. D. O’Brien, R. A Locarnini, T. P. Boyer, C. Stephens, and J. I. Antonov (2002), World Ocean Atlas 2001 vol. 4, Nutrients, NOAA Atlas NESDIS 52 , U.S. Govt. Print. Off., Washington, D. C.

Croot, P. L., A. R. Bowie, R. D. Frew, M. T. Maldonado, J. A. Hall, K. A. Safi, J. L. Roche, P. W. Boyd, and C. S. Law (2001), Retention of dissolved iron and FeII in an iron induced Southern Ocean phytoplankton bloom, Geophys. Res. Lett., 28, 3425-3428.

Cullen, J. T., B. A. Bergquist, and J. W. Moffett (2006), Thermodynamic characterization of the partitioning of iron between soluble and colloidal species in the Atlantic Ocean, Mar Chem., 98, 295-303.

Doney, S. C., K. Lindsay, I. Fung, and J. John (2006), Natural variability in a stable 1000 year global coupled climate-carbon cycle simulation, J. Clim., 19, 3033-3054.

Duce, R., and N. Tindale (1991), Atmospheric transport of iron and its deposition in the ocean, Limnol. Oceanogr., 36, 1715-1726.

Dutkiewicz, S., M. Follows, and P. Parekh (2005), Interactions of the iron and phosphorus cycles: A three-dimensional model study, Global Biogeochem. Cycles, 19 GB1021, doi:10.1029/2004GB002342.

Edwards, N. R., and R. Marsh (2005), Uncertainties due to transport-parameter sensitivity in an efficient 3-D ocean-climate model, Clim. Dyn. 3, 67-94.

Edwards, N. R., A. J. Willmott, and P. D. Killworth (1998), On the role of topography and wind stress on the stability of the thermohaline circulation, J. Phys. Oceanogr., 28, 756-778.

Falkowski, P. G., R. T. Barber, and V. Smetacek (1998), Biogeochemical controls and feedbacks on ocean primary productivity, Science, 281, 200-206

Gledhill, M., and C. van den Berg (1994), Determination of complexation of iron (III) with natural organic complexing ligands in seawate using cathodic stripping voltammetry, Mar Chem., 47, 41-54.

Gledhill, M., P. McCormack, S. Ussher, E. P. Achterberg, R. F. C. Mantoura, and P. Worsfold (2004), Production of siderophore type chelates by mixed bacterioplankton populations in nutrient enriched seawater incubations, Mar. Chem., 88, 75-83

Gnanadesikan, A., R. J. Slater, N. Gruber, and J. L. Sarmiento (2002), Oceanic vertical exchange and new production: A comparison between models and observations, Deep Sea. Res., Part II, 49, 363-401.

Gnanadesikan, A., J. P. Dunne, R. M. Key, K. Matsumoto, J. L. Sarmiento, R. D. Slater, and P. S. Swathi (2004), Oceanic ventilation and biogeochemical cycling: Understanding physical mechanisms that produce realistic distributions of tracers and productivity, Global Biogeochem. Cycles, 18, GB4010, doi:10.1029/ 2003 GB002097.

Haygood, M. G., P. D. Holt, and A. Butler (1993), Aerobactin production by a planktonic marine vibro sp., Limnol. Oceanogr., 38 $1091-1097$.

Hunter, K. A., and P. W. Boyd (2007), Ironbinding ligands and their role in the ocean biogeochemistry of iron, Environ. Chem., 4, $221-232$

Hutchins, D., A. Witter, A. Butler, and G. W Luther (1999), Competition among marine phytoplankton for different chelated iron species, Nature, 400, 858-860.

Indermühle, A., E. Monnin, B. Stauffer, T. Stocker, and M. Wahlen (2000), Atmospheric $\mathrm{CO}_{2}$ concentration from 60 to $20 \mathrm{kyr} \mathrm{BP}$ from the Taylor Dome ice core, Antarctica, Geophys. Res. Lett., 27, 735-738.

Johnson, K., F. Chavez, and G. Friederich (1999), Continental-shelf sediment as a primary source of iron for coastal phytoplankton, Nature, 398, 697-699.

Joos, F., J. Sarmiento, and U. Siegenthaler (1991), Estimates of the effect of Southern Ocean iron fertilization on atmospheric $\mathrm{CO}_{2}$ concentrations, Nature, 349, 772-775.

Köhler, P., F. Joos, S. Gerber, and R. Knutti (2005), Simulated changes in vegetation distribution, land carbon storage, and atmospheric $\mathrm{CO}_{2}$ in response to a collapse of the North Atlantic thermohaline circulation, Clim. Dyn., 25, 689-708.

Kurz, K. D., and E. Maier-Reimer (1993), Iron fertilization of the Austral Ocean: The Hamburg model assessment, Global Biogeochem Cycles, 7, 229-244.

Lambert, F., et al. (2008), Dust-climate couplings over the past 800,000 years from the EPICA Dome C ice core, Nature, 452, 616-619.

Laws, E. A., P. Falkowski, H. Ducklow, W. O. Smith, and J. J. McCarthy (2000), Temperature effects on export production in the open ocean, Global Biogeochem. Cycles, 14, 1231-1246.

Lefévre, N., and A. J. Watson (1999), Modeling the geochemical cycle of iron in the oceans and its impact on atmospheric $\mathrm{CO}_{2}$ concentrations, Global Biogeochem. Cycles, 13, 727-736.

Loulergue, L., F. Parrenin, T. Blunier, J. M. Barnola, R. Spahni, A. Schilt, G. Raisbeck, and J. Chappellaz (2007), New constraints on the gas age-ice age difference along the EPICA ice cores, 0-50 kyr, Clim. Past, 3, 527-540.

Loulergue, L., et al. (2008), Orbital and millennial-scale features of atmospheric $\mathrm{CH} 4$ over the past 800,000 years, Nature, 453, 383-386.

Luo, C., N. M. Mahowald, and J. del Corra (2003), Sensitivity study of meteorologica parameters on mineral aerosol mobilization, transport, and distribution, J. Geophys. Res. 108(D15), 4447, doi:10.1029/2003JD003483.

Lüthi, D., et al. (2008), High-resoultion carbon dioxide concentration record $650,000-$ 800,000 years before present, Nature, 453, $379-382$.

Macrellis, H., C. Trick, E. Rue, G. Smith, and K. Bruland (2001), Collection and detection of natural iron-binding ligands from seawater, Mar. Chem., 76, 175-187. 
Mahowald, N., K. Kohfeld, M. Hansson, Y. Balkanski, S. Harrison, I. Prentice, M. Schulz, and H. Rodhe (1999), Dust sources and deposition during the last glacial maximum and current climate: A comparison of model results with paleodata from ice cores and marine sediments, J. Geophys. Res., 104, 15,89515,916 .

Mahowald, N. M., D. R. Muhs, S. Levis, P. J. Rasch, M. Yoshioka, C. S. Zender, and C. Luo (2006), Change in atmospheric mineral aerosols in response to climate: Last glacial period, preindustrial, modern, and doubled carbon dioxide climates, J. Geophys. Res., 111, D10202, doi:10.1029/2005JD006653.

Marchal, O., T. F. Stocker, F. Joos, A. Indermühle, T. Blunier, and J. Tschumi (1999), Modelling the concentration of atmospheric $\mathrm{CO}_{2}$ during the Younger Dryas climate event, Clim. Dyn., 15, 341-354.

Martin, J. (1990), Glacial-interglacial $\mathrm{CO}_{2}$ change: The iron hypothesis, Paleoceanography, 5, 1-13.

Martin, J., G. Knauer, D. Karl, and W. Broenkow (1987), VERTEX: Carbon cycling in the northeast Pacific, Deep Sea Res., 34, 267-285.

Martin, J., et al. (1994), Testing the iron hypothesis in ecosystems of the equatorial Pacific Ocean, Nature, 371, 123-129.

McCormack, P., P. J. Worsfold, and M. Gledhill (2003), Separation and detection of siderophores produced by marine bacterioplankton using high-performance liquid chromatography with electrospray ionization mass spectrometry, Anal. Chem., 75, 2647-2652.

Merico, A., T. Tyrell, and P. A. Wilson (2008), Eocene/Oligocene ocean de-acidification linked to Antarctic glaciation by sea-level fall, Nature, 452, 979-983.

Moore, J. K., and O. Braucher (2008), Sedimentary and mineral dust sources of dissolved iron to the world ocean, Biogeosciences, 5, $631-656$.

Moore, J. K., S. C. Doney, and K. Lindsay (2004), Upper ocean ecosystem dynamics and iron cycling in a global three-dimensional model, Global Biogeochem. Cycles, 18, GB4028, doi:10.1029/2004GB002220.

Müller, S. A., F. Joos, N. R. Edwards, and T. F. Stocker (2006), Water mass distribution and ventilation time scales in a cost-efficient, three-dimensional ocean model, J. Clim., 19, 5479-5499.

Müller, S. A., F. Joos, G. K. Plattner, N. R. Edwards, and T. F. Stocker (2008), Modeled natural and excess radiocarbon: Sensitivities to the gas exchange formulation and ocean transport strength, Global Biogeochem. Cycles, 22, GB3011, doi:10.1029/2007GB003065.

Najjar, R. G., et al. (2007), Impact of circulation on export production, dissolved organic matter and dissolved oxygen in the ocean: Results from OCMIP-2, Global Biogeochem. Cycles, 21, GB3007, doi:10.1029/2006GB002857.

Parekh, P., M. Follows, and E. Boyle (2004),

Modeling the global ocean iron cycle, Global

Biogeochem. Cycles, 18, GB1002, doi:10.1029/ 2003GB002061.

Parekh, P., M. Follows, and E. Boyle (2005), Decoupling of iron and phosphate in the globa ocean, Global Biogeochem. Cycles, 19 GB2020, doi:10.1029/2004GB002280.

Parekh, P., S. Dutkiewicz, M. Follows, and T. Ito (2006a), Atmospheric carbon dioxide in a less dusty world, Geophys. Res. Lett., 33, L03610, doi:10.1029/2005GL025098.

Parekh, P., M. Follows, S. Dutkiewicz, and T. Ito (2006b), Physical and biological regulation of the soft tissue carbon pump, Paleoceanography, 21, PA3001, doi:10.1029/2005PA001258.

Peng, T. H., and W. S. Broecker (1991), Dynamical limitations on the Antarctic iron fertilization strategy, Nature, 349, 227-229.

Petit, J., et al. (1999), Climate and atmospheric history of the past 420,000 years from the Vostok ice core, Antarctica, Nature, 399 , 429-436.

Popova, E., V. Ryabchenko, and M. Fasham (2000), Biological pump and vertical mixing in the Southern Ocean: Their impact on atmospheric $\mathrm{CO}_{2}$, Global Biogeochem. Cycles, 14, $477-498$.

Röthlisberger, R., M. Bigler, E. W. Wolff, F Joos, E. Monnin, and M. A. Hutterli (2004), Ice core evidence for the extent of past atmospheric $\mathrm{CO}_{2}$ changes due to iron fertilisation, Geophys. Res. Lett., 31, L16207, doi:10.1029/ 2004GL020338.

Rue, E., and K. Bruland (1995), Complexation of iron (III) by natural organic ligands in the central North Pacific as determined by a new competitive ligand equilibration/adsorptive cathodic stripping voltammetric method, Mar Chem., 50, 117-138.

Rue, E., and K. Bruland (1997), The role of organic complexation on ambient iron chemistry in the equatorial Pacific Ocean and the response of a mesoscale iron addition experiment, Limnol. Oceanogr., 42, 901-910.

Sarmiento, J., and J. Orr (1991), Three-dimensional simulations of the impact of Southern Ocean nutrient depletion on atmospheric $\mathrm{CO}_{2}$ and ocean chemistry, Limnol. Oceanogr., 36, $1928-1950$

Schlitzer, R. (2000), Applying the adjoint method for biogeochemical modeling: Export of particulate organic matter in the World Ocean, in Inverse Methods, in Biogeochemical Cycles, Geophys. Monogr. Ser., vol. 114, edited by P. Kasibhatla et al., pp. 107-124, AGU, Washington, D. C.

Scholze, M., W. Knorr, and M. Heimann (2003), Modelling terrestrial vegetation dynamics and carbon cycling for an abrupt climate change event, Holocene, 13, 327-333.

Smith, W. O., and C. Lancelot (2004), Bottomup versus top-down control in phytoplankton of the Southern Ocean, Antarct. Sci., 16 $531-539$.

Sunda, W. G. (2001), Bioavailability and bioaccumulation of iron in the sea, in The Biogeochemistry of Iron in Seawater, pp. 41-84, John Wiley, Hoboken, N. J.

Town, R. M., and M. Filella (2000), Dispelling the myths: Is the existence of L1 and L2 ligands necessary to explain metal ion speciation in natural waters?, Limnol. Oceanogr., $45,1341-1357$

Trick, C. G., R. J. Andersen, N. M. Price, A. Gillam, and P. J. Harrison (1983), Examination of hydroxamate-siderophore production by neritic eucaryotic phytoplankton Mar. Biol., 75, 9-17.

Tsuda, A., et al. (2003), A mesoscale iron enrichment in the western subarctic Pacific induces a large centric diatom bloom, Science, 300 958-961.

Voelker, B. M., and M. B. Kogut (2001), Interpretation of metal speciation data in coastal waters: The effects of humic substances on copper binding as a test case, Mar. Chem. 74, 303-318.

Winckler, G., R. F. Anderson, M. Q. Fleisher, D. McGee, and N. Mahowald (2008), Covariant glacial-interglacial dust fluxes in the equatorial Pacific and Antarctica, Science, 320, 93-96.

Witter, A., D. Hitchins, A. Butler, and G. Luther (2000), Determination of conditional stability constants and kinetic constants for strong mode Fe-binding ligands in seawater, Mar. Chem., 69 , $1-17$.

Wu, J., E. Boyle, W. Sunda, and L. Wen (2001), Soluble and colloidal iron in the oligotrophic North Atlantic and North Pacific, Science, 293 847-849.

Yamanaka, Y., and E. Tajika (1997), Role of dissolved organic matter in the marine biogeochemical cycles: Studies using an ocean biogeochemical general circulation-model, Global Biogeochem. Cycles, 4, 599-612.

F. Joos and P. Parekh, Climate and Environmental Physics, Physics Institute, University of Bern, Sidlerstrasse 5, CH-3012 Bern, Switzerland. (parekh@climate.unibe.ch)

S. A. Müller, Department of Earth and Environmental Sciences, Open University, Milton Keynes MK7 6AA, UK. 